\title{
Prevalence of dental caries and antemortem tooth loss at Pacopampa in an initial stage of social stratification in Peru's northern highlands
}

\author{
Tomohito Nagaoka ${ }^{1 *}$, Yuji Seki ${ }^{2}$, Kazuhiro Uzawa $^{3}$, Wataru Morita ${ }^{4}$, Daniel Morales Chocano \\ ${ }^{1}$ Faculty of Management and Economics, Aomori Public University, Aomori 030-0196, Japan \\ ${ }^{2}$ National Museum of Ethnology, Suita 565-8511, Japan \\ ${ }^{3}$ Department of Humanities and Social Sciences, University of East Asia, Shimonoseki 751-8503, Japan \\ ${ }^{4}$ Department of Anthropology, National Museum of Nature and Science, Tsukuba 305-0005, Japan \\ ${ }^{5}$ Universidad Nacional Mayor de San Marcos, Lima 15081, Peru
}

Received 12 April 2021; accepted 5 May 2021

\begin{abstract}
This study examined the occurrence of carious lesions and antemortem tooth loss (AMTL) in skeletal remains from Pacopampa, a Formative period site in Peru. We sought to identify variations in carious lesions and AMTL within and between groups to uncover insights into social stratification and subsistence. Targets were permanent teeth and alveoli from skeletal remains from the Pacopampa I (1200-700 BCE) and Pacopampa II (700-400 BCE) phases. In this study, rates of carious lesions and AMTL were analyzed in relation to cultural phase, age, sex, and burial type. The results revealed that rates varied by age (AMTL rates increased with age), sex (females exhibited higher carious and AMTL rates than males), and burial type (individuals buried with precious goods demonstrated lower carious and AMTL rates than other individuals). It is concluded that skeletal remains from the early stages of Andean social stratification revealed significant variations in dental caries and AMTL across cultural and biological factors. This study identified differences in the appearance of carious lesions and AMTL rates during the emergence of social stratification in the Central Andes in the Formative period. Future studies that explore diet using stable isotopic data are needed to test the assumption that variations in dental caries and AMTL are related to dietary patterns.
\end{abstract}

Key words: dental caries, antemortem tooth loss, dental wear, social stratification, Andean civilization

\section{Introduction}

Bioarchaeology of dental caries and antemortem tooth loss Dental caries result from a disease process in which acid produced by the bacterial fermentation of carbohydrates causes focal demineralization of hard dental tissues (Larsen, 2015). The pathogenesis of caries involves the tooth surface being exposed to, among other things, the oral environment, oral bacterial flora, salivary glycoprotein, dental plaques, diet, crown size and morphology, enamel defects, occlusal surface wear, and oral pH (Larsen, 2015). In bioarchaeological contexts, dental caries has been linked to carbohydrate intake quantity; notably, agriculturists who ingested soft, sticky foods and sugars have exhibited a high prevalence of caries (Hillson, 1990, 2008). Differences in the prevalence of carious lesions, and thus carbohydrate intake, have also

\footnotetext{
* Correspondence to: Tomohito Nagaoka, Faculty of Management and Economics, Aomori Public University, 153-4 Yamazaki, Goshizawa, Aomori 030-0196, Japan.

E-mail: nagaoka@b.nebuta.ac.jp

Published online 22 July 2021

in J-STAGE (www.jstage.jst.go.jp) DOI: 10.1537/ase.210505
}

been found between social classes (Sakura, 1964; White, 1994; Sakashita et al., 1997; Whittington, 1999; Cucina and Tiesler, 2003; Oyamada et al., 2004; Klaus et al., 2010).

Periodontal disease is associated with alveolar bone loss, such as horizontal bone loss relative to the cementoenamel junction and vertical bone loss around an individual tooth (Hillson, 1996). It impairs the skeletal support of teeth and eventually results in antemortem tooth loss (AMTL). Once alveolar bone loss occurs, the tooth socket is destined to be obliterated through remodeling. The causes of periodontal disease are multifactorial and include bacteria, poor oral hygiene, cariogenesis, malocclusion, nutritional stress, pregnancy, and teeth being subject to extreme mechanical loads (Larsen, 2015). In particular, bioarchaeologists have associated the shift from hunting-gathering to farming with increased periodontal disease and AMTL in North America's Western Woodlands (Patterson, 1984) and Egypt's Nile Valley (Rose et al., 1993). While some scholars also found that the prevalence of AMTL varies by social class and sex due to differences in diet and food consumption practices (Costa, 1980; Frayer, 1984), only a handful of studies have been done on this topic to date.

Both carious and AMTL rates vary widely according to 
subsistence, social class, sex, and age. However, it remains unclear how developments in sociality and subsistence, especially as related to the emergence of stratified societies, may have affected variation in dental caries and AMTL. Using Andean civilization skeletal remains from the initial stage of its social stratification and subsistence development, we compared the prevalence of carious lesions and AMTL within and between groups and assessed the causative factors contributing to any variations.

\section{Archaeological settings}

The Formative period (3000-50 BCE) in the Central Andes is characterized by the rise and development of the Andean civilization (Burger, 1992; Onuki, 1998; Onuki et al., 2010). Large monumental complexes first appeared in the Supe Valley, on the central coast of Peru, around 3000 BCE (Shady et al., 2001). In recent years, there have been reports of cases dating back to $3000 \mathrm{BCE}$ and cases of contemporaneous monumental complexes in the central and northcentral coast (Haas and Creamer, 2006). During the Middle and Late Formative periods (700-250 BCE), the construction and renovation of public architecture occurred; these activities promoted population growth and social integration in the Central Andes (Onuki, 1998). These innovations promoted social integration during the Formative period at Huacaloma, located in the northern highlands; however, no evidence of social hierarchy has been found at this site (Terada and Onuki, 1982). This contrasts with evidence from investigations into other sites in the northern highlands, such as Kuntur Wasi and Ingatambo, as well as in the southern highlands at Campanayuq Rumi. At Kuntur Wasi, social differentiation was evident in the more than seven tombs found comprising complex, boot-shaped structures that contained gold objects, Ecuadorian shell ornaments, and Bolivian sodalite beads (Seki, 2014). Moreover, the individuals buried in these tombs showed evidence of being subject to artificial cranial deformation (Seki, 2014): their crania were partially covered with cinnabar, which would have been imported from Peru's central highlands - these findings suggest that the individuals buried in these tombs at Kuntur Wasi were members of an elite group (Seki, 2014). Meanwhile, recent excavations at Ingatambo in the Huancabamba Valley have also yielded evidence social stratification; more specifically, excavators found large and complex ceremonial architectures and indications of long-distance exchanges of precious goods during the Ingatambo phase (800-400 BCE) (Yamamoto, 2012). Last, social stratification is also evident in the gold metallurgy recovered from a Campanayuq Rumi site from the Late Formative period (800-200 BCE) (Matsumoto and Cavero Palomino, 2012): a gold artifact and ceramic casting mold indicate technological innovations from simple hammering techniques common during the Early and Middle Formative periods (1800-800 BCE) metallurgy (Matsumoto and Cavero Palomino, 2012). Although the large monumental complexes in the Supe Valley have been dated back to around $3000 \mathrm{BCE}$, the above recent archaeological data from Kuntur Wasi, Ingatambo, and Campanayuq Rumi demonstrates that social stratification likely appeared in the Central Andes during the Late Formative period (800-200 BCE).
We began our archaeological project at Pacopampa in 2005. Pacopampa is a Formative period site along the eastern slope of Peru's northern highlands with an altitude of $2500 \mathrm{~m}$ above sea level (Figure 1). It is set back roughly $70 \mathrm{~km}$ from the Pacific coast and far from Peru's tropical riverbanks. The Pacopampa site was composed of three large, low platforms, which covered a total area of approximately 4 hectares (Figure 2). The platforms surrounded a sunken plaza (Figure 2). Elaborate subterranean canal systems seem to have played an important role in rituals related to water and agricultural production (Seki et al., 2008). The presence of large-scale public architecture, the plaza, decorated stone sculptures, and archaeological remains related to rituals suggest that the site functioned as a ceremonial center (Seki et al., 2008). Reconstructions of means of subsistence from zooarchaeological and stable isotope data revealed that the site demonstrated an increased use of domesticated plants and animals (Uzawa, 2008; Takigami and Yoneda, 2017).

Our Pacopampa archaeological project led to important findings concerning socioeconomic inequality during the Formative period. Notably, the westernmost platform may have been the most important religious space in the complex. From that platform, an adult female (Individual No. 09PC-C-Ent 09-2-H2) was recovered from an elite tomb with a boot-shaped structure (the 'Lady of Pacopampa' tomb) dated to the beginning of the Pacopampa II phase (700-400 BCE). Cinnabar and azurite were found on the skull along with a pair of gold earplugs, a pair of gold earrings, and shell-based objects (Figure 3b; Table 1) (Nagaoka et al., 2012b). The bright red cinnabar was sourced from cinnabar ore mined in Huancavelica, over $850 \mathrm{~km}$ to the

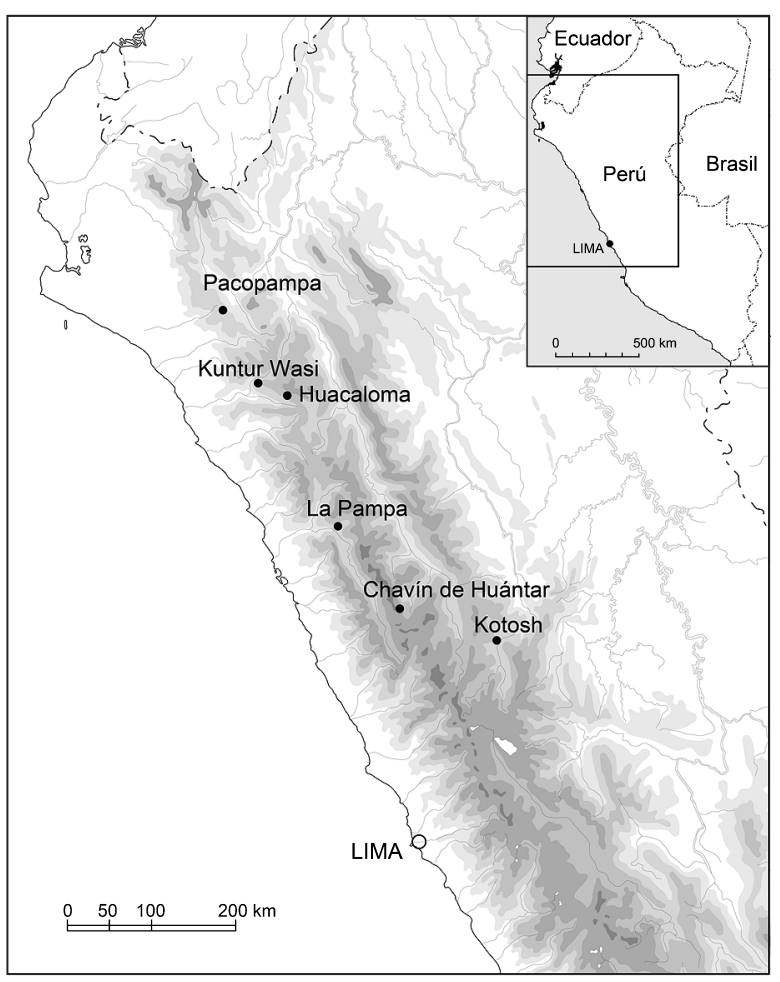

Figure 1. Map of Peru showing the location of Pacopampa. 


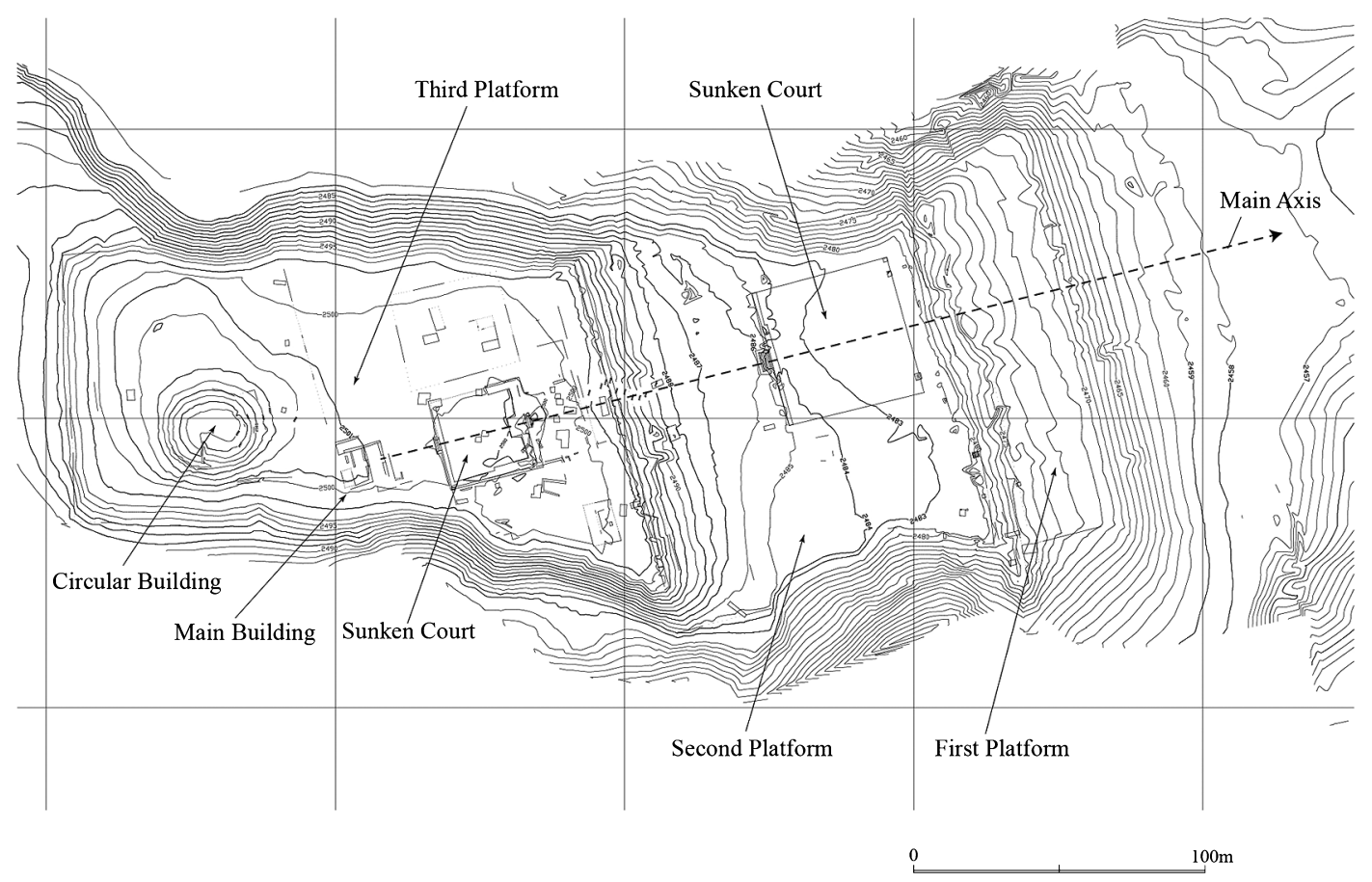

Figure 2. Map of the ceremonial complex at Pacopampa.

south (Burger et al., 2016). A detailed examination of the neurocranium revealed the presence of a frontal-occipital type of artificial cranial deformation, which had previously only been found with human remains that, based on the precious burial goods found with them, appeared to be from the highest social class (Nagaoka et al., 2012b).

The project further detected another elite tomb with a boot-shaped structure (the 'Serpent-Jaguar Priests' tomb) from which we recovered two individuals (Individual No. 15PC-B2-Ent 541-H1 and -H2) from the Pacopampa II phase (Figure 3g, h; Table 1) (Nagaoka et al., 2020). At the bottom of the tomb, a middle-aged female was found lying over the remains of a 15-year-old male (Nagaoka et al., 2020). The central position of the tomb and a rich repertoire of grave goods, including gold ornaments and pigments, suggest that these individuals had symbolic importance and belonged to an elite social group (Nagaoka et al., 2020). The possible presence of artificial cranial deformation in the female suggests that these buried individuals were socially different from the other individuals found buried at this site (Nagaoka et al., 2020).

Figure 3 shows individuals from elaborate burials associated with gold and silver ornaments, pigments, and artificial cranial deformation. In total, our 11-year excavations yielded one fetal individual associated with pigments (Figure 3f) in the Pacopampa I phase (1200-700 BCE) and nine adult individuals associated with gold and silver ornaments, pigments, and artificial cranial deformation (Figure 3a-e, g, h) from the Pacopampa II phase (700-400 BCE) (Table 1). The precious goods found in their graves and their special burial treatment suggest that social inequality at Pacopampa may date back at least to the Pacopampa II phase. A variety of exotic artifacts from the northern coast allow us to trace the wide-ranging connections kept by the ceremonial center and the patterns of exchange that were essential to maintaining the prestige of Pacopampa and its elites (Seki et al., 2008). The Pacopampa site offers some of the earliest evidence of a highly stratified society in the Central Andes and our data from Pacopampa, detailed below, offer new insights into the relationship between social development and pathology.

\section{The purpose of this study}

Human remains from well-contextualized burials are ideal for clarifying the impact of social stratification on the prevalence of caries and AMTL. In order to clarify the relationship between social stratification and dental pathology, this study aimed to examine the occurrence of carious lesions and AMTL from Pacopampa and compare observed variations within and between groups to uncover causative factors.

\section{Materials}

We conducted our study over 11 field seasons from 2005 to 2015. This work yielded the remains of 103 individuals from the Formative period, comprising 38 non-adults (under 15 years) and 65 adults ( 15 years or older) (Nagaoka et al., 2017, 2019). Archaeological artifacts, architecture, stratigraphy, and radiocarbon dating revealed that the chronological ages of the human remains belonged to the Middle Formative period (Pacopapma I phase; 1200-700 BCE) and the earlier half of the Late Formative period (Pacopapma II phase; 700-400 BCE). Beta Analytic, a laboratory in Miami, FL, USA, conducted radiocarbon dating of the bones.

Because the materials were excavated from the ceremoni- 

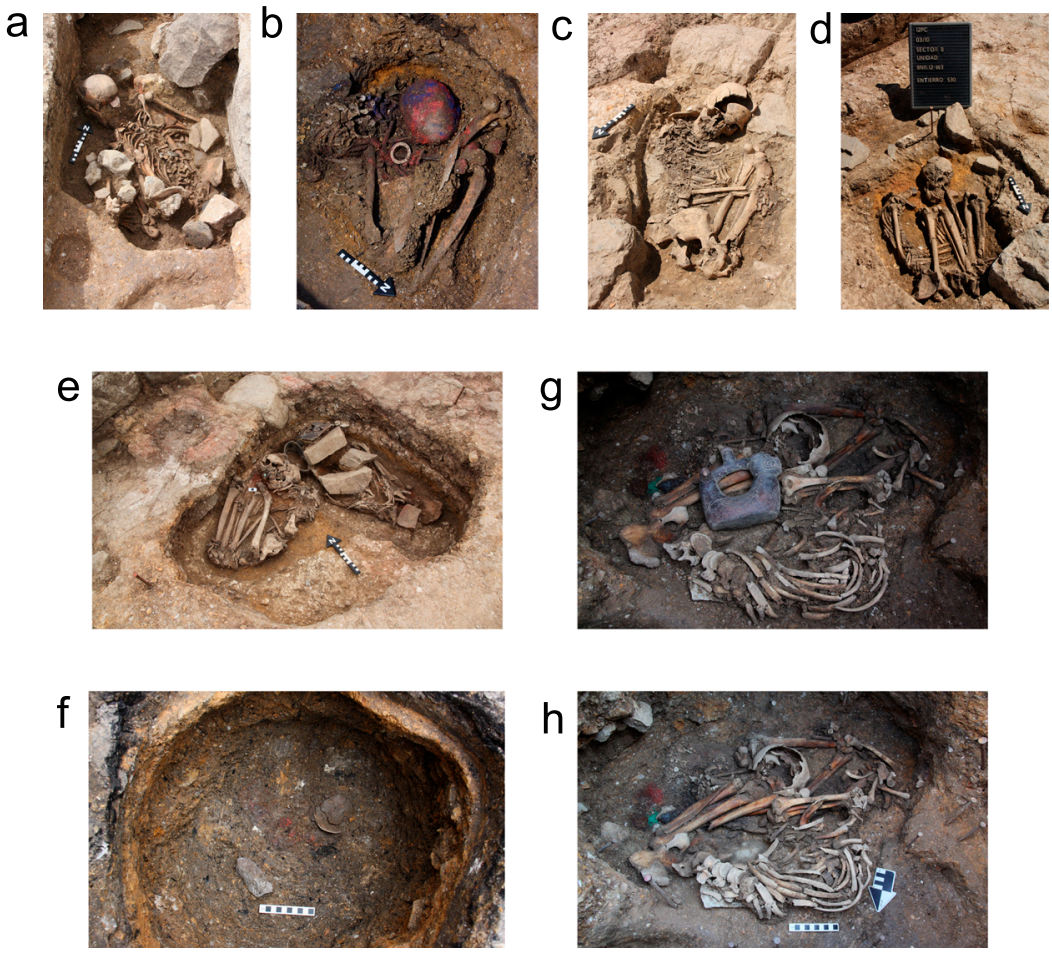

Figure 3. Individuals from elaborate burials associated with gold and silver ornaments, pigments, and artificial cranial deformation: (a) A younger male, individual No. 09PC-B2-Ent 509; (b) a younger female, individual No. 09PC-C-Ent 09-2-H2; (c) a younger male, individual No. 12PC-B2-Ent 527-H1; (d) a younger female, individual No. 12PC-B2-Ent 530; (e) older and younger females, individual No. 12PC-B2-Ent 532-H1 and 12PC-B2-Ent 532-H2, respectively; (f) a fetus, individual No. 12PC-C-Ent 12-03; (g) a younger female, individual No. 15PC-B2-Ent 541-H1; and (h) a younger male, individual No. 15PC-B2-Ent 541-H2.

al center, they may all have played special roles in ritual activities. Assuming that the found precious objects, pigments, and artificial cranial deformations serve as proxies of social class, we wagered that our materials comprised remains from different social classes. The target of this study was the permanent teeth and alveoli from the remains of 65 adult human ( 3 individuals from the Pacopapma I phase and 62 individuals from the Pacopapma II phase). All individuals represent individuals with well-contextualized stratigraphic origins.

The materials were curated by the Pacopampa Archaeological Project and temporarily housed at the Center for $\mathrm{Pa}-$ copampa Archaeological Project (Jr. Bolognesi, Centro Poblado de Pacopampa, Distrito de Querocoto, Provincia de Chota, Region Cajamarca, Peru) under the permission of the Peruvian Ministry of Culture.

\section{Methods}

\section{Age-at-death estimation and sex determination}

We estimated the ages of non-adult skeletons based on dental development (Ubelaker, 1989), measurements of temporal and occipital bones (Nagaoka et al., 2012a; Nagaoka and Kawakubo, 2015), ilia (Ubelaker, 1989), and limb bones (Scheuer et al., 1980), as well as closure of the occipital synchondrosis (Wakebe, 1990) and the epiphyseal union of the ilia and long bones (Buikstra and Ubelaker, 1994). We classified the ages of adults aged 15 years or older at the time of death into two categories due to the small sample size: younger (15-54 years) and older ( $\geq 55$ years), based on the chronological metamorphosis of the auricular surface of the ilium (Lovejoy et al., 1985; Buckberry and Chamberlain, 2002), pubic symphysis (Todd, 1920, 1921; Brooks and Suchey, 1990), first ribs (Kunos et al., 1999), and dental wear (Lovejoy, 1985).

We determined the sex of individuals aged $\geq 15$ years based on a macroscopic assessment of pelvic and cranial traits (Phenice, 1969; Bruzek, 2002; Walker, 2008).

\section{Classification of burial types}

Several individuals were excavated from elaborate burials associated with gold and silver ornaments, pigments, and artificial cranial deformation. In this study, these individuals and those who were buried with them were classified as a higher-class burial type; meanwhile, those lacking these elements were classified as a lower-class burial type. The terms 'higher' and 'lower' here are relative and, because they were all derived from ceremonial centers at Pacopampa, are used to signify 'elaborate' and 'unelaborated' burial contexts rather than 'elite' and 'non-elite' subjects.

It is highly likely that the subterranean construction of the tombs of the 'Lady of Pacopampa' and 'Serpent-Jaguar Priests' played an important role in maintaining the prestige of Pacopampa and its elites. In contrast, it is difficult to estimate the social classes of the remaining skeletons because little is known about their roles in the society. Although the 
DENTAL CARIES AND ANTEMORTEM TOOTH LOSS AT PACOPAMPA 5

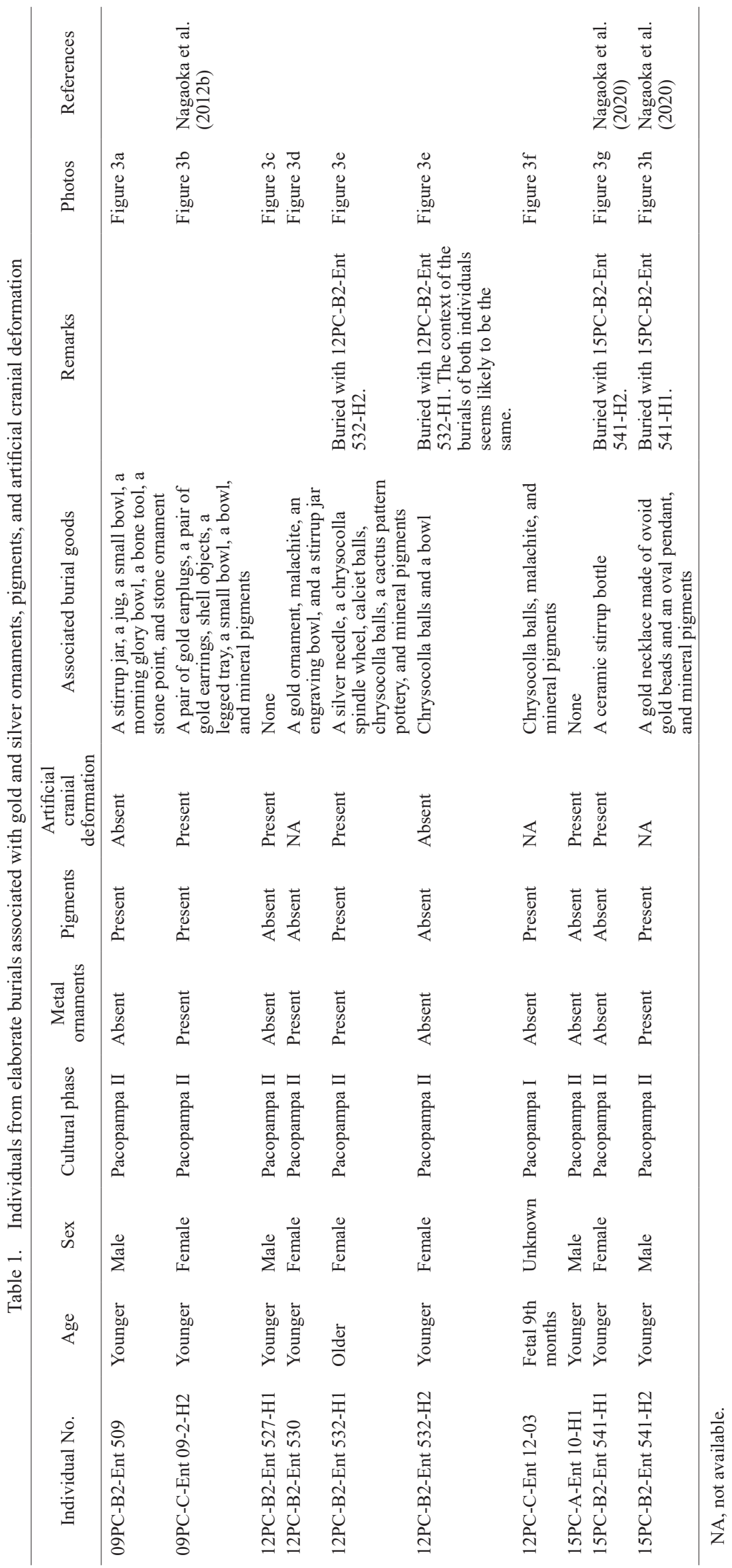




\section{a}

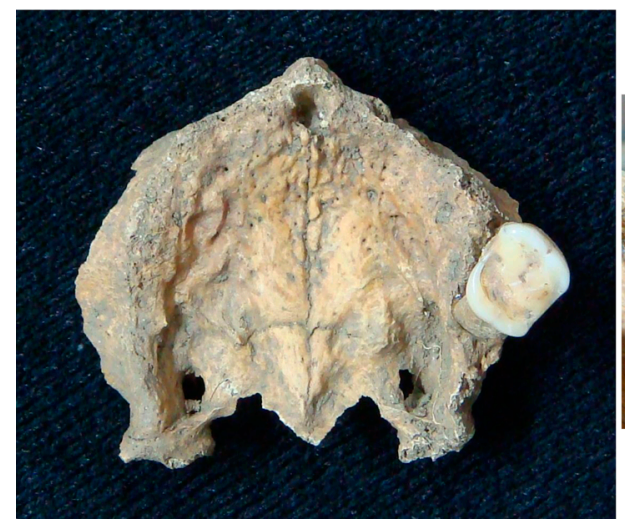

b

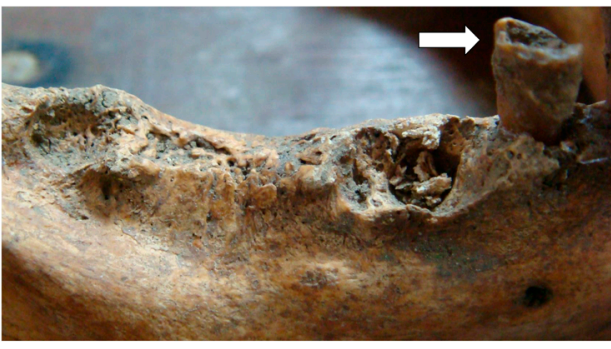

Figure 4. (a) Maxilla showing antemortem tooth loss (AMTL), and (b) right side of mandible showing AMTL and caries (right lower second premolar) (white arrow). An older female, individual No. 06PC-A-H11.

presence of precious grave goods and pigments as well as artificial cranial deformation may be proxies of an elite class, this reading cannot be taken as a verified truth. Using the prevalence of dental caries and AMTL as a bioarchaeological lifestyle indicator, we tested whether variations existed in the prevalence of these dental diseases according to burial context to explore the relationship between pathology and social stratification.

\section{Dental caries (Figure 4)}

Teeth were observed by the naked eye using a dental explorer. When carious lesions were detected, a $\times 10$ magnifying glass was used for further observations. Radiographic analyses were not possible because permission was not obtained to transport the skeletal remains to our institutions.

\section{Carious rates}

Carious rates were calculated by total tooth units (i.e. number of affected teeth/total number of teeth observed) (Lukacs, 1995). Carious rates were analyzed based on cultural phase, age, sex, and burial type (as categorized above), to enable examination of their contribution to the carious variability in the initial stage of social stratification in the Central Andes.

\section{Carious depth}

The degree of carious depth was classified into four stages according to the diagnostic criteria by Sakashita et al. (1997) and the modified version by Lanfranco and Eggers (2010).

Stage 1: The extent of caries is limited to the enamel layer. The lack of decalcification of the enamel in which a dental probe cannot be inserted was excluded.

Stage 2: The carious cavity does not reach the dental pulp and is limited to the dentin. The apex of a dental probe is buried more than $2 \mathrm{~mm}$ into a cavity in the dentin.

Stage 3: The carious cavity reaches the dental pulp and is often associated with abscesses and granuloma.

Stage 4: Tooth crowns are destroyed by dental decay, severe dental wear, and trauma.

\section{Carious location}

The carious location was classified into eight categories according to the diagnostic criteria of Hillson $(1996,2001)$ and the modified version of Lanfranco and Eggers (2010). Lanfranco and Eggers (2010) defined eight scores for the carious location as follows.

Score 1: Occlusal caries in the fissures, grooves, and fossae of molars and premolars. Occlusal caries of molars often occurs in deep fissures without pathological changes in surfaces and are difficult to diagnose by macroscopy alone (Hillson 2001). We identified occlusal caries from the presence of both staining and cavities on the occlusal surface.

Score 2: Pit caries in the buccal pits of molars and lingual pits of incisors and canines.

Score 3: Smooth surface caries in the buccal/labial and lingual enamel smooth surfaces.

Score 4: Contact area caries appearing in the approximal area between two teeth.

Score 5: Smooth surface caries in the approximal surface below the contact area between two teeth in the coronal cervical third, not involving the cementum-enamel junction (CEJ).

Score 6: Root caries in the root surface and CEJ.

Score 7: Occlusal attrition facet dentin caries and occlusal attrition facet enamel edge chipping and caries associated with intense dental wear.

Score 8. Gross-gross caries caused by intense and rapid dental wear is sufficient to surpass the capacity of secondary dentin production.

When a tooth was affected by multiple caries with different depths on different surfaces, the highest score of location and depth was adopted to express cariogenicity and carious severity (Lanfranco and Eggers, 2010). In order to provide comparative data of carious location of the Andes, this study employed the eight categories established by Lanfranco and Eggers (2010). 


\section{AMTL (Figure 4)}

We observed missing teeth according to the criteria by Hillson $(1996,2001)$, who referred to a missing tooth that left an empty socket with signs of remodeling or a missing tooth with full remodeling that left no contour of the socket. AMTL rates were calculated by the number of missing teeth per the total number of alveoli observed.

\section{Dental wear}

In general, dental wear is negatively correlated with caries (Hillson 1990, 2008). This study recorded dental wear on a scale ranging from stage 1 to stage 8 , according to the diagnostic criteria of Molnar (1971).

Stage 1: No observable wear.

Stage 2: Minimal evidence of wear observable in incisors and canines; no dentin observable in premolars and molars.

Stage 3: Observable obliterated cusp pattern and small dentin patches.

Stage 4: Minimal dentin patches observable in incisors and canines, two or more dentin patches observable in premolars, and three or more small dentin patches observable in molars.

Stage 5: Extensive dentin patches were observed in the incisors and canines; two or more dentin patches and slight secondary dentin observable in premolars; and three or more small dentin patches and none to slight secondary dentin observable in molars.

Stage 6: Secondary dentin observable in incisors and canines; moderate to heavy secondary dentin and entire tooth surrounded by enamel and observable in premolars and molars.

Stage 7: Crown is worn away on at least one side and extensive secondary dentin is observable.

Stage 8: Roots functioning in occlusal surfaces.

\section{Statistical analyses}

Fisher's exact test with Bonferroni correction was used to analyze contingency tables in the software package $\mathrm{R}$ 3.5.2 (R Core Team, 2018). The significance levels of $P<0.01$ and $P<0.05$ were respectively corrected into $P<0.0009$ $(0.01 / 11)$ and $P<0.0045(0.05 / 11)$ because we performed Fisher's exact test for 11 dentition groups

\section{Results}

\section{Carious rates}

The proportion of carious teeth was $17.2 \%$ of 1760 teeth (303/1760) (Supplementary Table 1). The proportion of carious teeth was $10.7 \%(3 / 28)$ in younger females in the Pacopampa I phase (Supplementary Table 1). In the Pacopampa II phase, the proportion of affected teeth was $3.7 \%(4 / 107)$ for higher-class younger females, $26.9 \%$ (7/26) for higherclass older females, and 8.3\% (11/133) for higher-class younger and older females; meanwhile, these proportions were $16.6 \%(51 / 308)$ for lower-class younger females, $49.1 \%$ (28/57) for lower-class older females, and 21.6\% (79/365) for lower-class younger and older females (Supplementary Table 1$)$. The proportion was $0.0 \%(0 / 73)$ for high- er-class younger males, whereas these proportions were $18.0 \%(58 / 322)$ for lower-class younger males, $21.1 \%$ (4/19) for lower-class older males, and 18.2\% (62/341) for lower-class younger and older males (Supplementary Table 1).

The results of Fisher's exact tests indicated significant differences by age and burial type: carious rates increased from younger to older females both in higher-class $(P=0.0009)$ and lower-class $(P<0.0001)$ burials (Figure 5a; Table 2); lower-class individuals had higher carious rates than higher-class individuals in younger females $(P=0.0004)$, younger and older females $(P<0.0001)$, and younger males $(P=0.0004)$ (Figure $5 \mathrm{c}$; Table 2$)$. In contrast, there was no significant difference in carious rates between cultural phases $(P>0.0045)$ (Table 2$)$.

\section{Carious depth}

In all groups, the most frequent carious depth was stage 2, in which the carious cavity is limited to dentin (Supplementary Table 2). The rates of carious depth stages did not show any significant differences according to cultural phase, age, sex, and burial type (Table 3 ).

\section{Carious location}

The most frequent carious location was root caries in all groups (Supplementary Table 3). Within the Pacopampa II phase, younger males from lower-class burials had more frequent occlusal caries (score 1), smooth surface caries in the buccal/labial and lingual enamel smooth surface (score 3 ), contact area caries in the approximal area (score 4), smooth surface caries on the approximal surface (score 5), and gross-gross caries (score 8 ) than younger females from lower-class burials $(P=0.0003)$ (Table 4$)$.

\section{Number of carious lesions per tooth}

The proportion of carious teeth with one carious lesion was greater than those with more than one carious lesion in all age groups (Supplementary Table 4). Rates of carious depth stages did not show any significant differences according to cultural phase, age, sex, and burial type (Table 5).

\section{AMTL rates}

The proportion of AMTL was $12.6 \%$ of 2014 alveoli (254/2014) (Supplementary Table 1). The proportion of AMTL was $0.0 \%(0 / 28)$ in younger females in the Pacopampa I phase (Table 2). In the Pacopampa II phase, the proportions of affected teeth were $0.9 \%(1 / 108)$ for higher-class younger females, $0.0 \%(0 / 26)$ for higher-class older females, and $0.7 \%(1 / 134)$ for higher-class younger and older females; meanwhile, these proportions were $14.2 \%(51 / 359)$ for lower-class younger females, $41.8 \%$ (41/98) for lowerclass older females, and 20.1\% (92/457) for lower-class younger and older females (Supplementary Table 1). The proportion of AMTL was $0.0 \%(0 / 73)$ for higher-class younger males; meanwhile, these proportions were $9.0 \%$ (32/354) for lower-class younger males, 17.4\% (4/23) for lower-class older males, and 9.5\% (36/377) for lower-class younger and older males (Supplementary Table 1).

The results of Fisher's exact tests showed the significant differences by age, sex, and burial type. The proportion of 


\section{Age differences}

Caries

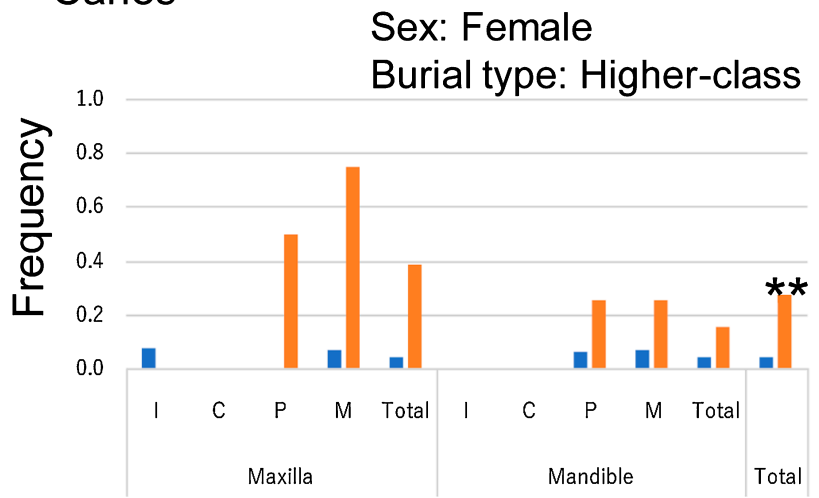

Caries

Sex: Female

Burial type: Lower-class

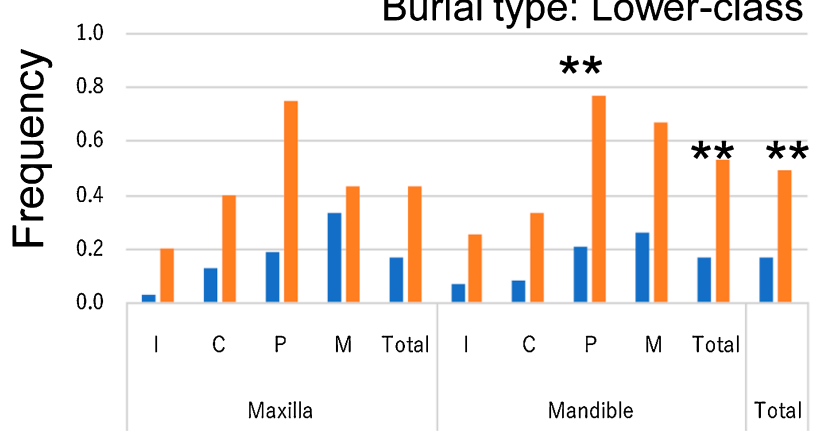

Caries

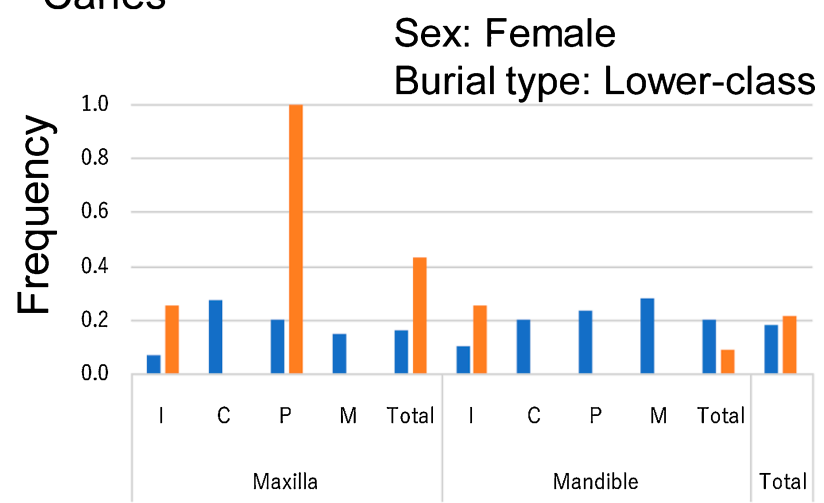

AMTL

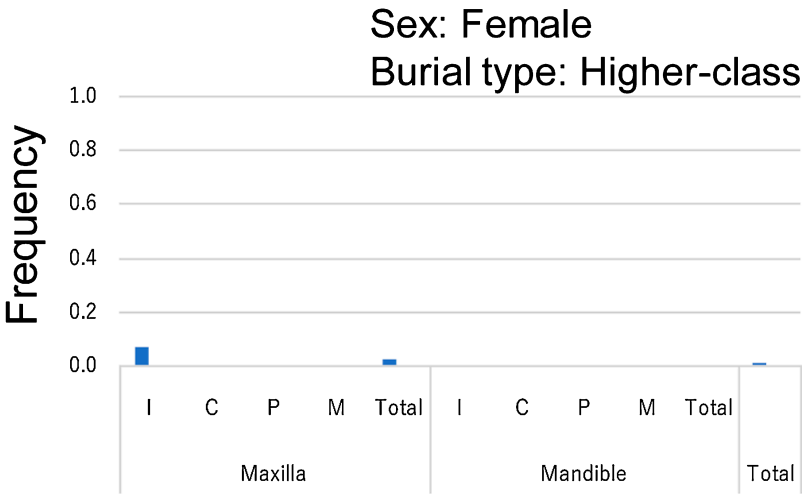

AMTL

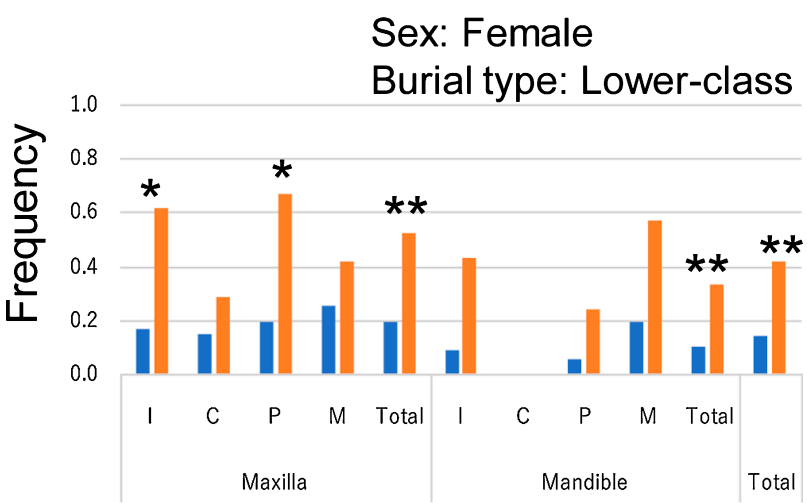

AMTL

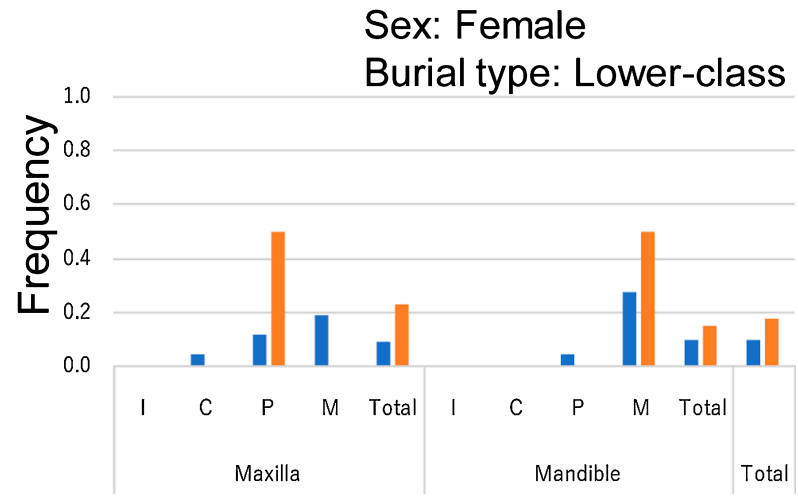

Sex: Female

\section{Older}

Figure 5. Comparison of carious rates and antemortem tooth loss (AMTL) rates according to ages (a), sexes (b), and burial types (c). The significance levels of $* * P<0.01$ and $* P<0.05$ were respectively corrected to $P<0.0009(0.01 / 11)$ and $P<0.0045(0.05 / 11)$. 
b

\section{Sex differences}

\section{Caries}

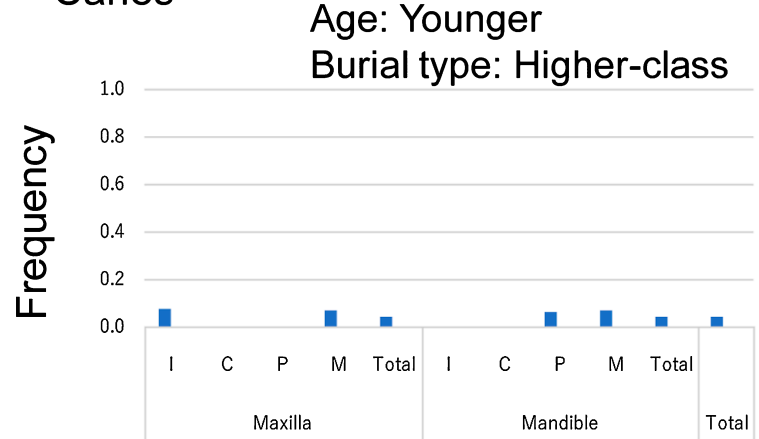

\section{Caries}

Age: Younger

Burial type: Lower-class
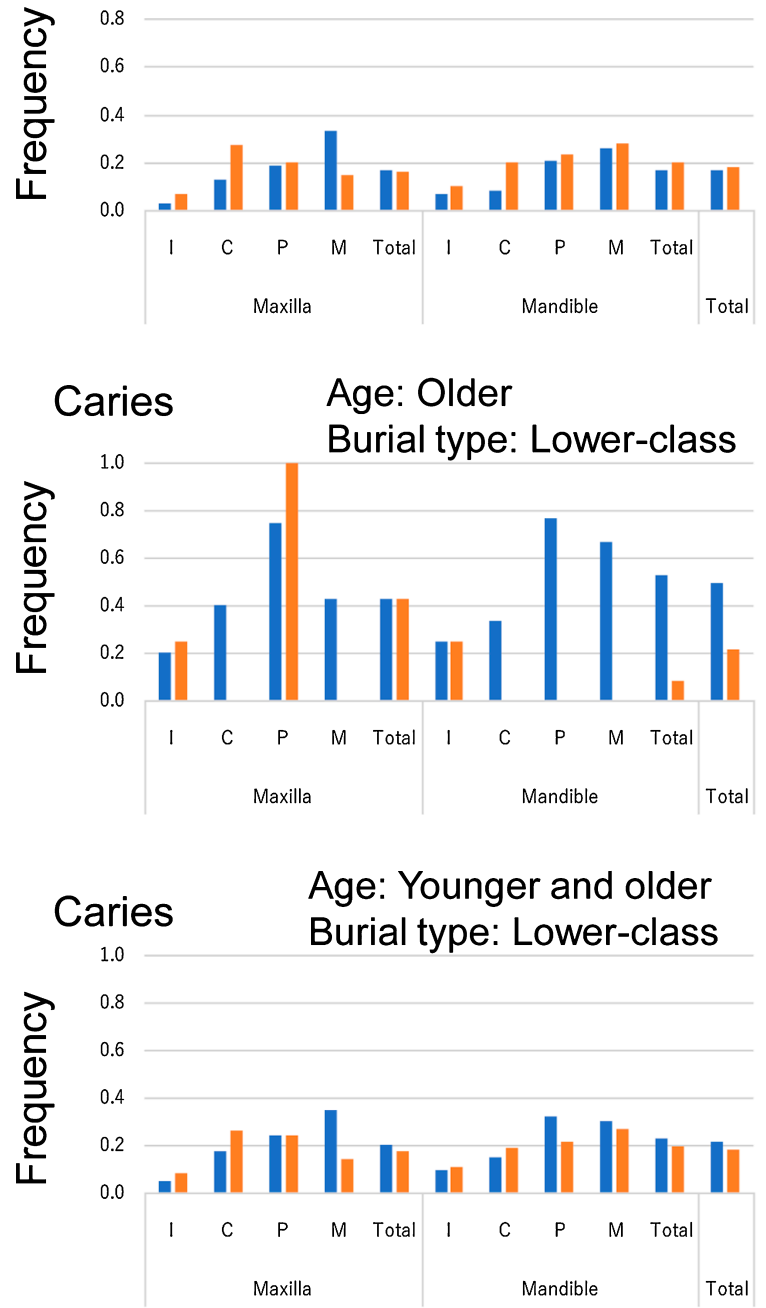
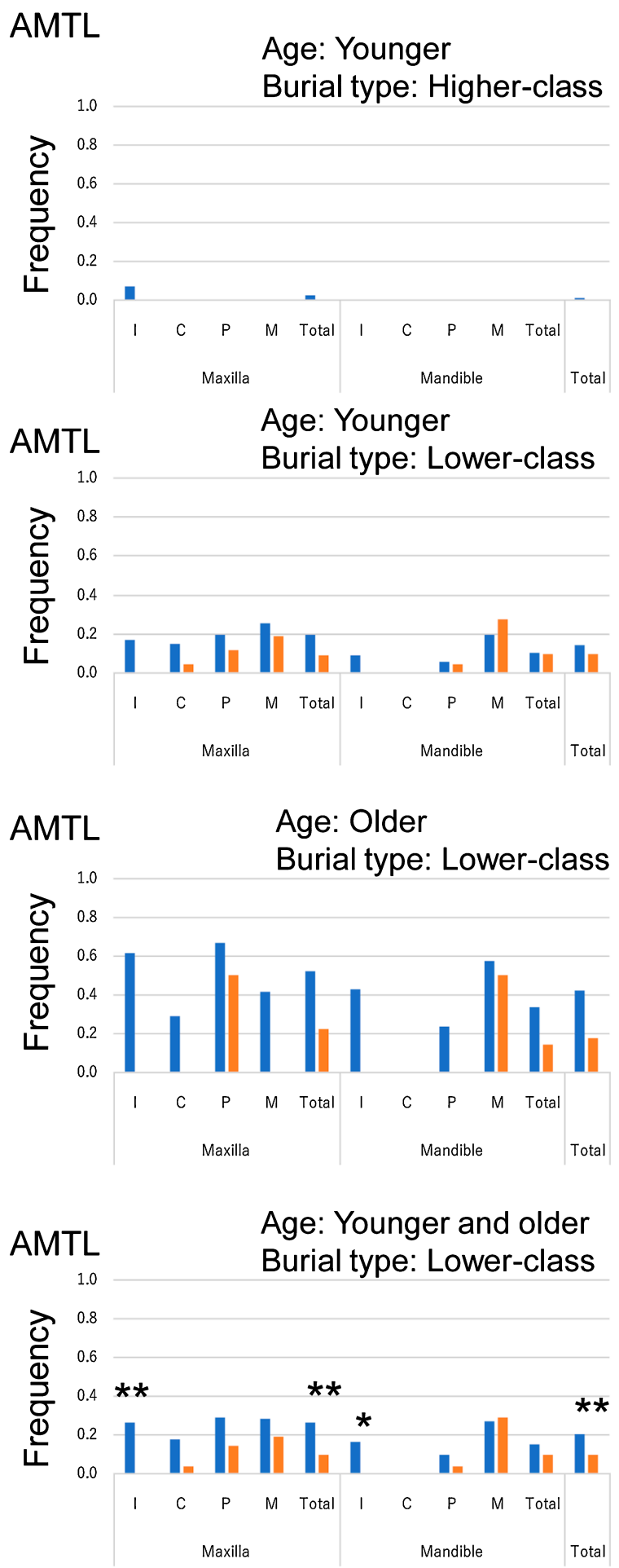

Female
Male

Figure 5. (continued) 


\section{Burial differences}

\section{Caries}
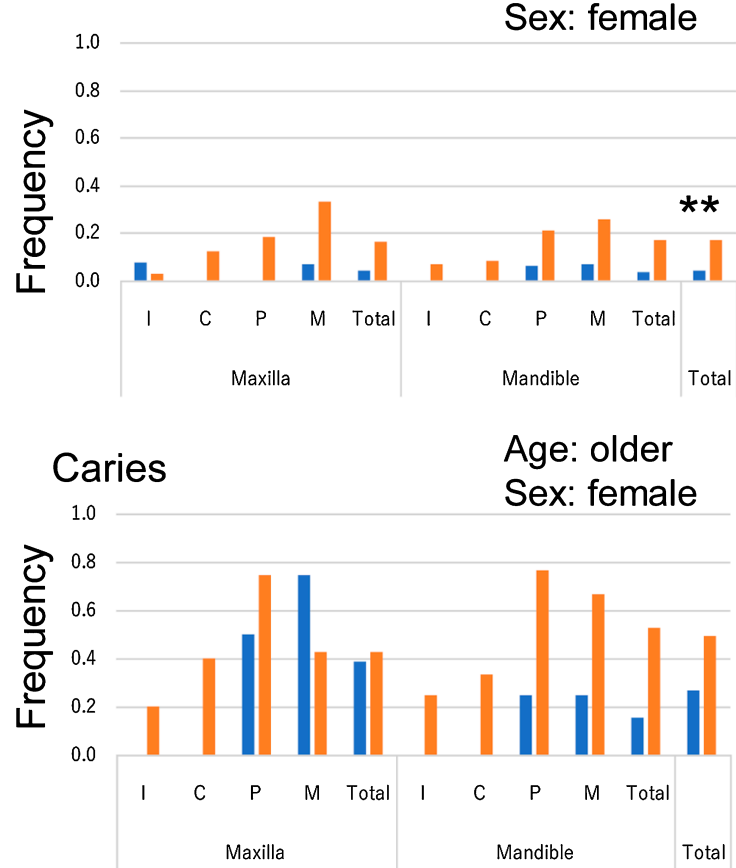

Caries

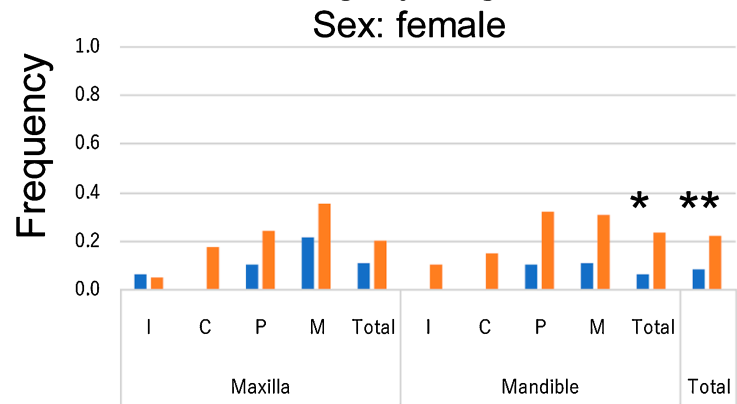

Caries

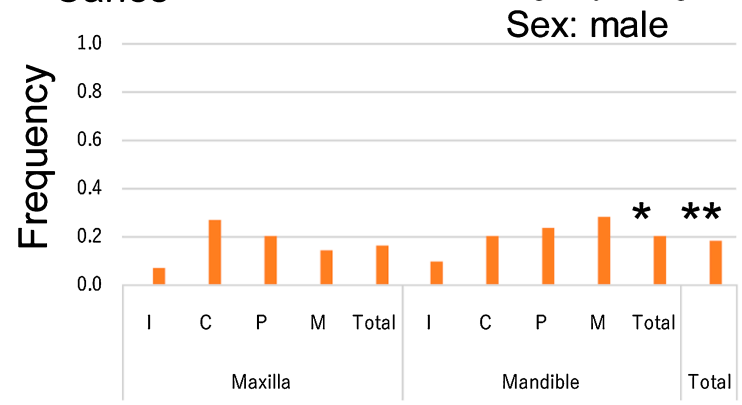

AMTL

Age: younger

Sex: female

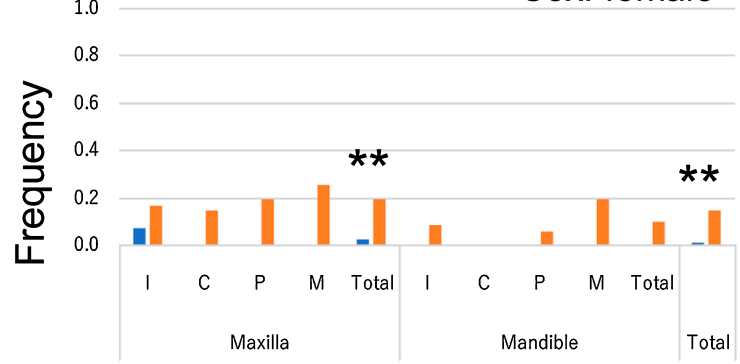

AMTL

Age: older

Sex: female

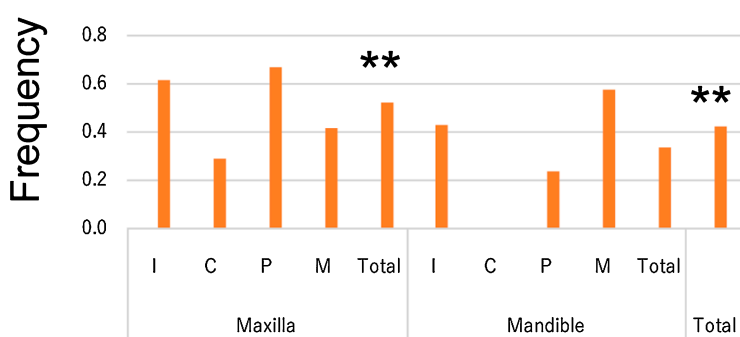

AMTL

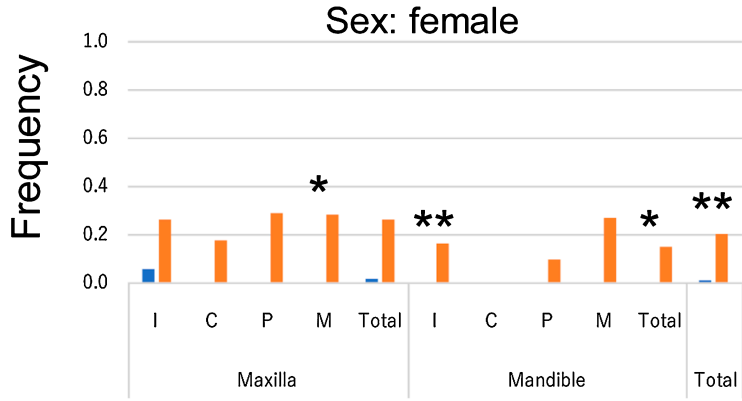

AMTL

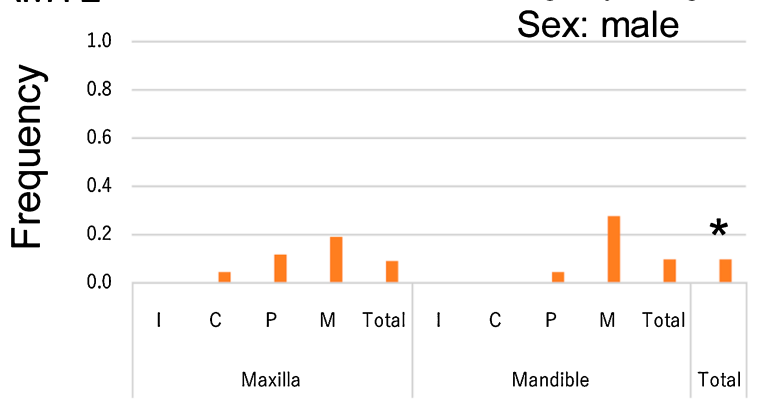

Age: younger

Sex: male

\section{Lower-class}

Figure 5. (continued) 
Table 2. Fisher's exact test of carious rates and AMTL rates according to cultural phases, ages, sexes, and burial types

\begin{tabular}{|c|c|c|c|c|c|c|c|c|c|c|c|c|c|}
\hline \multicolumn{14}{|c|}{ Comparison between cultural phases (Pacopampa I vs. II) } \\
\hline \multirow{2}{*}{ Ages } & \multirow{2}{*}{ Sexes } & \multirow{2}{*}{ Rates } & \multicolumn{5}{|c|}{ Maxilla } & \multicolumn{5}{|c|}{ Mandible } & \multirow{2}{*}{ Total } \\
\hline & & & I & $\mathrm{C}$ & $\mathrm{P}$ & M & Total & I & $\mathrm{C}$ & $\mathrm{P}$ & M & Total & \\
\hline \multirow[t]{2}{*}{ Younger } & \multirow[t]{2}{*}{ Females } & \multirow{2}{*}{$\begin{array}{l}\text { Carious rates } \\
\text { AMTL rates }\end{array}$} & ns & ns & ns & ns & ns & ns & ns & ns & ns & ns & \multirow{2}{*}{$\begin{array}{l}\mathrm{ns} \\
\mathrm{ns}\end{array}$} \\
\hline & & & ns & ns & $\mathrm{ns}$ & $\mathrm{ns}$ & ns & ns & ns & ns & $\mathrm{ns}$ & ns & \\
\hline \multicolumn{14}{|c|}{ Comparison between ages in the Pacopampa II phase (younger vs. older) } \\
\hline \multirow{2}{*}{ Sexes } & \multirow{2}{*}{ Burial tyapes } & \multirow{2}{*}{ Rates } & \multicolumn{5}{|c|}{ Maxilla } & \multicolumn{5}{|c|}{ Mandible } & \multirow{2}{*}{ Total } \\
\hline & & & I & $\mathrm{C}$ & $\mathrm{P}$ & M & Total & I & $\mathrm{C}$ & $\mathrm{P}$ & $\mathrm{M}$ & Total & \\
\hline \multirow[t]{2}{*}{ Females } & \multirow[t]{2}{*}{ Higher-class } & Carious rates & ns & ns & ns & ns & $\mathrm{O}>\mathrm{Y}$ & ns & ns & ns & ns & ns & \multirow{2}{*}{$\begin{array}{c}\mathrm{O}>>\mathrm{Y} \\
\mathrm{ns}\end{array}$} \\
\hline & & AMTL rates & $\mathrm{ns}$ & $\mathrm{ns}$ & $\mathrm{ns}$ & $\mathrm{ns}$ & $\mathrm{ns}$ & $\mathrm{ns}$ & ns & ns & ns & ns & \\
\hline \multirow[t]{2}{*}{ Females } & \multirow[t]{2}{*}{ Lower-class } & Carious rates & ns & $\mathrm{ns}$ & ns & ns & ns & ns & ns & $\mathrm{O}>>\mathrm{Y}$ & ns & $\mathrm{O} \gg>\mathrm{Y}$ & $\mathrm{O}>>\mathrm{Y}$ \\
\hline & & AMTL rates & $\mathrm{O}>\mathrm{Y}$ & $\mathrm{ns}$ & $\mathrm{O}>\mathrm{Y}$ & $\mathrm{ns}$ & $\mathrm{O}>>\mathrm{Y}$ & $\mathrm{ns}$ & ns & ns & $\mathrm{ns}$ & $\mathrm{O} \gg>\mathrm{Y}$ & $\mathrm{O}>>\mathrm{Y}$ \\
\hline \multirow[t]{2}{*}{ Males } & Lower-class & Carious rates & $\mathrm{ns}$ & $\mathrm{ns}$ & ns & ns & ns & $\mathrm{ns}$ & ns & $\mathrm{ns}$ & ns & ns & ns \\
\hline & & AMTL rates & $\mathrm{ns}$ & ns & $\mathrm{ns}$ & $\mathrm{ns}$ & ns & $\mathrm{ns}$ & ns & $\mathrm{ns}$ & $\mathrm{ns}$ & ns & ns \\
\hline Comparison between & sexes in the $\mathrm{Pa}$ & copampa II pha & (female & ma & & & & & & & & & \\
\hline Ages & & & & & Maxill & & & & & Mandib & & & \\
\hline Ages & Burral tyapes & Rates & $\mathrm{I}$ & $\mathrm{C}$ & $\mathrm{P}$ & M & Total & I & $\mathrm{C}$ & $\mathrm{P}$ & M & Total & Total \\
\hline Younger & Higher-class & Carious rates & $\mathrm{ns}$ & $\mathrm{ns}$ & $\mathrm{ns}$ & $\mathrm{ns}$ & $\mathrm{ns}$ & $\mathrm{ns}$ & $\mathrm{ns}$ & $\mathrm{ns}$ & $\mathrm{ns}$ & $\mathrm{ns}$ & ns \\
\hline & & AMTL rates & $\mathrm{ns}$ & $\mathrm{ns}$ & $\mathrm{ns}$ & $\mathrm{ns}$ & ns & $\mathrm{ns}$ & ns & ns & ns & $\mathrm{ns}$ & $\mathrm{ns}$ \\
\hline Younger & Lower-class & Carious rates & $\mathrm{ns}$ & $\mathrm{ns}$ & $\mathrm{ns}$ & $\mathrm{ns}$ & $\mathrm{ns}$ & $\mathrm{ns}$ & ns & ns & ns & $\mathrm{ns}$ & $\mathrm{ns}$ \\
\hline & & AMTL rates & ns & ns & ns & ns & ns & ns & ns & ns & ns & ns & ns \\
\hline Older & Lower-class & Carious rates & $\mathrm{ns}$ & ns & $\mathrm{ns}$ & $\mathrm{ns}$ & $\mathrm{ns}$ & $\mathrm{ns}$ & ns & $\mathrm{ns}$ & $\mathrm{ns}$ & $\mathrm{ns}$ & $\mathrm{ns}$ \\
\hline & & AMTL rates & $\mathrm{ns}$ & $\mathrm{ns}$ & $\mathrm{ns}$ & $\mathrm{ns}$ & $\mathrm{ns}$ & ns & ns & ns & $\mathrm{ns}$ & $\mathrm{ns}$ & $\mathrm{ns}$ \\
\hline Younger and older & Lower-class & Carious rates & ns & ns & ns & ns & ns & $\mathrm{ns}$ & ns & ns & ns & ns & ns \\
\hline & & AMTL rates & $\mathrm{F}>>\mathrm{M}$ & $\mathrm{ns}$ & $\mathrm{ns}$ & $\mathrm{ns}$ & $\mathrm{F}>>\mathrm{M}$ & $\mathrm{F}>\mathrm{M}$ & ns & $\mathrm{ns}$ & $\mathrm{ns}$ & $\mathrm{ns}$ & $\mathrm{F}>>\mathrm{M}$ \\
\hline Comparison between & burial types in & the Pacopampa & I phase $(1$ & her-c & is vs. lc & er-class & & & & & & & \\
\hline$\Delta \mathrm{coc}$ & Seyer & Patec & & & Maxill & & & & & Mandib & & & \\
\hline Ages & Sexes & Rates & $\mathrm{I}$ & $\mathrm{C}$ & $\mathrm{P}$ & $\mathrm{M}$ & Total & $\mathrm{I}$ & $\mathrm{C}$ & $\mathrm{P}$ & M & Total & Total \\
\hline Younger & Females & Carious rates & $\mathrm{ns}$ & $\mathrm{ns}$ & ns & ns & ns & ns & ns & ns & $\mathrm{ns}$ & ns & $\mathrm{L} \gg>\mathrm{H}$ \\
\hline & & AMTL rates & ns & ns & ns & ns & $\mathrm{L}>>\mathrm{H}$ & ns & ns & $\mathrm{ns}$ & $\mathrm{ns}$ & $\mathrm{ns}$ & $\mathrm{L} \gg>\mathrm{H}$ \\
\hline Older & Females & Carious rates & ns & ns & ns & $\mathrm{ns}$ & ns & ns & ns & $\mathrm{ns}$ & ns & ns & ns \\
\hline & & AMTL rates & $\mathrm{ns}$ & $\mathrm{ns}$ & ns & $\mathrm{ns}$ & $\mathrm{L}>>\mathrm{H}$ & $\mathrm{ns}$ & ns & $\mathrm{ns}$ & $\mathrm{ns}$ & ns & $\mathrm{L} \gg>\mathrm{H}$ \\
\hline Younger and older & Females & Carious rates & $\mathrm{ns}$ & ns & ns & $\mathrm{ns}$ & ns & $\mathrm{ns}$ & ns & $\mathrm{ns}$ & $\mathrm{ns}$ & $\mathrm{L}>\mathrm{H}$ & $\mathrm{L} \gg>\mathrm{H}$ \\
\hline & & AMTL rates & ns & ns & ns & $\mathrm{L}>\mathrm{H}$ & ns & $\mathrm{L}>>\mathrm{H}$ & ns & $\mathrm{ns}$ & ns & $\mathrm{L}>\mathrm{H}$ & $\mathrm{L} \gg>\mathrm{H}$ \\
\hline Younger & Males & Carious rates & $\mathrm{ns}$ & $\mathrm{ns}$ & $\mathrm{ns}$ & ns & $\mathrm{ns}$ & $\mathrm{ns}$ & ns & $\mathrm{ns}$ & $\mathrm{ns}$ & $\mathrm{L}>\mathrm{H}$ & $\mathrm{L} \gg>\mathrm{H}$ \\
\hline & & AMTL rates & $\mathrm{ns}$ & $\mathrm{ns}$ & ns & $\mathrm{ns}$ & ns & ns & ns & $\mathrm{ns}$ & $\mathrm{ns}$ & $\mathrm{ns}$ & $\mathrm{L}>\mathrm{H}$ \\
\hline
\end{tabular}

AMTL, antemortem tooth loss; Y, younger; O, older; F, female, M, male; H, higher-class burial; L, lower class burial; ns, not significant.

The significance levels of $P<0.01$ and $P<0.05$ were respectively corrected to $P<0.0009(0.01 / 11)$ and $P<0.0045(0.05 / 11)$. They are respectively shown by $>>$ and $>$.

AMTL in upper incisors $(P=0.0024)$, upper premolars $(P=0.0027)$, upper total teeth $(P<0.0001)$, lower total teeth $(P=0.0001)$, and total teeth $(P<0.0001)$ increased with age in lower-class females (Figure 5a; Table 2). Females exhibited higher rates of AMTL than males in upper incisors $(P<0.0001)$, upper total teeth $(P<0.0001)$, lower incisors $(P=0.0001)$, and total teeth $(P<0.0001)$ in lowerclass younger and older individuals (Figure $5 b$; Table 2 ). Lower-class individuals had higher rates of AMTL than higher-class individuals in younger females $(P<0.0001)$, older females $(P<0.0001)$, younger and older females $(P<0.0001)$, and younger males $(P=0.0028)$ (Figure $5 \mathrm{c}$; Table 2). Turning to the comparison of AMTL rates between cultural phases in lower-class younger females, no significant differences were observed $(P>0.0045)$ (Table 2).

\section{Dental wear rate}

The proportions of teeth with the eight different types of dental wear were compared according to cultural phase, age, sex, and burial type (Table 6). Dental wear at stages $2-3$ was most frequent in younger age groups, and the severity of dental wear increased with age (Supplementary Table 5). The results of Fisher's exact tests indicated that there was no significant difference in dental wear between cultural phases $(P>0.0045)$ (Table 6). Within the Pacopampa II phase, significant differences in dental wear stages were observed across age, sex, and burial type. Dental wear severity increased with age in higher-class females $(P=0.0001)$, lower-class females $(P<0.0001)$, and lower-class males $(P<0.0001)$ (Figure 6a; Table 6). Females exhibited more severe dental wear than males in higher-class younger $(P<0.0001)$, lower-class younger $(P<0.0001)$, and lower- 
Table 3. Fisher's exact test of rates of carious depth stages according to cultural phases, ages, sexes, and burial types

\begin{tabular}{|c|c|c|c|c|c|c|c|c|c|c|c|c|}
\hline \multirow{2}{*}{ Ages } & \multirow{2}{*}{ Sexes } & \multicolumn{5}{|c|}{ Maxilla } & \multicolumn{5}{|c|}{ Mandible } & \multirow{2}{*}{ Total } \\
\hline & & I & $\mathrm{C}$ & $\mathrm{P}$ & M & Total & I & $\mathrm{C}$ & $\mathrm{P}$ & M & Total & \\
\hline Younger & Females & ns & N/A & N/A & ns & ns & N/A & N/A & ns & ns & ns & ns \\
\hline \multicolumn{13}{|c|}{ Comparison between ages in the Pacopampa II phase (younger vs. older) } \\
\hline \multirow{2}{*}{ Sexes } & \multirow{2}{*}{ Burial tyapes } & \multicolumn{5}{|c|}{ Maxilla } & \multicolumn{5}{|c|}{ Mandible } & \multirow{2}{*}{ Total } \\
\hline & & I & $\mathrm{C}$ & $\mathrm{P}$ & M & Total & I & $\mathrm{C}$ & $\mathrm{P}$ & M & Total & \\
\hline Females & Higher-class & ns & N/A & ns & ns & $\mathrm{ns}$ & N/A & N/A & ns & ns & ns & ns \\
\hline Females & Lower-class & ns & ns & ns & ns & $\mathrm{ns}$ & $\mathrm{ns}$ & $\mathrm{ns}$ & ns & $\mathrm{ns}$ & ns & $\mathrm{ns}$ \\
\hline Males & Lower-class & ns & $\mathrm{ns}$ & ns & ns & ns & ns & ns & ns & ns & ns & ns \\
\hline \multicolumn{13}{|c|}{ Comparison between sexes in the Pacopampa II phase (female vs. male) } \\
\hline \multirow{2}{*}{ Ages } & \multirow{2}{*}{ Burial tyapes } & \multicolumn{5}{|c|}{ Maxilla } & \multicolumn{5}{|c|}{ Mandible } & \multirow{2}{*}{ Total } \\
\hline & & $\mathrm{I}$ & $\mathrm{C}$ & $\mathrm{P}$ & M & Total & I & $\mathrm{C}$ & $\mathrm{P}$ & M & Total & \\
\hline Younger & Higher-class & ns & N/A & $\mathrm{N} / \mathrm{A}$ & ns & ns & N/A & N/A & ns & ns & ns & ns \\
\hline Younger & Lower-class & ns & $\mathrm{ns}$ & ns & ns & ns & $\mathrm{ns}$ & $\mathrm{ns}$ & ns & ns & ns & ns \\
\hline Older & Lower-class & ns & $\mathrm{ns}$ & ns & ns & ns & ns & ns & ns & ns & ns & ns \\
\hline Younger and older & Lower-class & ns & ns & ns & ns & ns & ns & $\mathrm{ns}$ & ns & ns & ns & ns \\
\hline \multicolumn{13}{|c|}{ Comparison between burial types in the Pacopampa II phase (higher-class vs. lower-class) } \\
\hline \multirow{2}{*}{ Ages } & \multirow{2}{*}{ Sexes } & \multicolumn{5}{|c|}{ Maxilla } & \multicolumn{5}{|c|}{ Mandible } & \multirow[t]{2}{*}{ Total } \\
\hline & & I & $\mathrm{C}$ & $\mathrm{P}$ & M & Total & $\mathrm{I}$ & $\mathrm{C}$ & $\mathrm{P}$ & M & Total & \\
\hline Younger & Females & ns & ns & ns & ns & ns & ns & ns & ns & ns & ns & ns \\
\hline Older & Females & ns & ns & ns & ns & ns & $\mathrm{ns}$ & ns & ns & ns & ns & ns \\
\hline Younger and older & Females & ns & ns & ns & ns & ns & $\mathrm{ns}$ & ns & $\mathrm{ns}$ & $\mathrm{ns}$ & $\mathrm{ns}$ & ns \\
\hline Younger & Males & ns & ns & $\mathrm{ns}$ & ns & $\mathrm{ns}$ & ns & ns & ns & ns & $\mathrm{ns}$ & ns \\
\hline
\end{tabular}

ns, not significant.

The significance levels of $* * P<0.01 * *$ and $* P<0.05$ were respectively corrected to $P<0.0009(0.01 / 11)$ and $P<0.0045(0.05 / 11)$.

class younger and older $(P<0.0001)$ groups (Figure $6 \mathrm{~b}$; Table 6). Furthermore, individuals from lower-class burials exhibited more severe dental wear than those from higherclass burials in younger females $(P<0.0001)$, younger and older females $(P<0.0001)$, and younger males $(P<0.0001)$ (Figure 6c; Table 6). Incisors also exhibited significant differences in dental wear stages across age, sex, and burial type (at least $P<0.0045$ ) (Table 6). In summary, those who were 'older,' 'female,' and 'lower-class' demonstrated more severe dental wear than those who were 'younger,' 'male,' and 'higher-class.'

\section{Discussion}

\section{Dental wear and its influences on caries and AMTL at Pacopampa}

This study examined the severity of dental wear at Pacopampa and compared it across cultural phase, age, sex, and burial type. The results showed variations according to age (the severity of dental wear increased with age), sex (females had more severe dental wear than males), and burial type (individuals from lower-class burials had more severe dental wear than those from higher-class burials) (Table 6).

Typically, there is a negative correlation between dental wear and carious rates because severe dental wear often eliminates occlusal caries (Maat and Van der Velde, 1987). At Pacopampa, younger males from lower-class burials had frequent occlusal caries (score 1), smooth surface caries in the buccal/labial and lingual enamel smooth surface (score 3 ), contact area caries in the approximal area (score 4), smooth surface caries in the approximal surface (score 5), and gross-gross caries (score 8); meanwhile, younger females from lower-class burials predominantly demonstrated root caries (score 6) (Table 6). This difference suggests that occlusal caries in females with more severe occlusal wear than males decreased with the progress of dental wear on occlusal surfaces. Therefore, we inferred that the negative relationship between dental wear and carious rates may be reflected in sexual dimorphism in carious location.

However, rapid and intense dental wear resulting in pulp exposure may increase caries and AMTL, yielding a positive relationship between dental wear and caries. This study further indicated a positive relationship between dental wear and caries in teeth inconsistent with this general trend. Indeed, older females from lower-class burials with a higher proportion of severe dental wear $(4.2 \%$ with stage 8 dental wear) than any other group demonstrated a high proportion of AMTL (41.8\%) (Table 2). In addition, the proportion of carious lesions resulting from severe dental wear (grossgross caries in stage 8 carious location) was $42.9 \%$ in older females from higher-class burials, which was the highest across all groups (Supplementary Table 5). Those with severe dental wear at Pacopampa were likely at high risk of caries and AMTL. Dental wear is related to a decrease in 
Table 4. Fisher's exact test of rates of carious location scores according to cultural phases, ages, sexes, and burial types

\begin{tabular}{|c|c|c|c|c|c|c|c|c|c|c|c|c|}
\hline \multirow{2}{*}{ Ages } & \multirow{2}{*}{ Sexes } & \multicolumn{5}{|c|}{ Maxilla } & \multicolumn{5}{|c|}{ Mandible } & \multirow{2}{*}{ Total } \\
\hline & & I & $\mathrm{C}$ & $\mathrm{P}$ & M & Total & I & $\mathrm{C}$ & $\mathrm{P}$ & M & Total & \\
\hline Younger & Females & ns & ns & ns & ns & ns & ns & ns & ns & ns & ns & ns \\
\hline \multicolumn{13}{|c|}{ Comparison between ages in the Pacopampa II phase (younger vs. older) } \\
\hline \multirow{2}{*}{ Sexes } & \multirow{2}{*}{ Burial tyapes } & \multicolumn{5}{|c|}{ Maxilla } & \multicolumn{5}{|c|}{ Mandible } & \multirow{2}{*}{ Total } \\
\hline & & I & $\mathrm{C}$ & $\mathrm{P}$ & M & Total & I & $\mathrm{C}$ & $\mathrm{P}$ & $\mathrm{M}$ & Total & \\
\hline Females & Higher-class & ns & NA & ns & ns & $\mathrm{ns}$ & NA & NA & ns & ns & $\mathrm{ns}$ & ns \\
\hline Females & Lower-class & $\mathrm{ns}$ & $\mathrm{ns}$ & ns & ns & ns & ns & $\mathrm{ns}$ & $\mathrm{ns}$ & $\mathrm{ns}$ & $\mathrm{ns}$ & $\mathrm{ns}$ \\
\hline Males & Lower-class & ns & $\mathrm{ns}$ & $\mathrm{ns}$ & $\mathrm{ns}$ & ns & ns & ns & ns & ns & ns & $\mathrm{ns}$ \\
\hline \multicolumn{13}{|c|}{ Comparison between sexes in the Pacopampa II phase (female vs. male) } \\
\hline \multirow{2}{*}{ Ages } & \multirow{2}{*}{ Burial tyapes } & \multicolumn{5}{|c|}{ Maxilla } & \multicolumn{5}{|c|}{ Mandible } & \multirow{2}{*}{ Total } \\
\hline & & $\mathrm{I}$ & $\mathrm{C}$ & $\mathrm{P}$ & M & Total & I & $\mathrm{C}$ & $\mathrm{P}$ & M & Total & \\
\hline Younger & Higher-class & NA & NA & NA & NA & NA & NA & NA & NA & NA & NA & NA \\
\hline Younger & Lower-class & ns & ns & ns & $\mathrm{ns}$ & ns & ns & ns & $\mathrm{ns}$ & ns & ns & $*$ \\
\hline Older & Lower-class & ns & $\mathrm{ns}$ & ns & ns & ns & ns & ns & ns & ns & ns & ns \\
\hline Younger and older & Lower-class & $\mathrm{ns}$ & ns & ns & ns & ns & ns & ns & ns & ns & ns & ns \\
\hline \multicolumn{13}{|c|}{ Comparison between burial types in the Pacopampa II phase (higher-class vs. lower-class) } \\
\hline \multirow{2}{*}{ Ages } & \multirow{2}{*}{ Sexes } & \multicolumn{5}{|c|}{ Maxilla } & \multicolumn{5}{|c|}{ Mandible } & \multirow{2}{*}{ Total } \\
\hline & & $\mathrm{I}$ & $\mathrm{C}$ & $\mathrm{P}$ & M & Total & $\mathrm{I}$ & $\mathrm{C}$ & $\mathrm{P}$ & M & Total & \\
\hline Younger & Females & ns & ns & ns & ns & ns & ns & ns & $\mathrm{ns}$ & ns & ns & ns \\
\hline Older & Females & ns & ns & ns & ns & ns & ns & ns & $\mathrm{ns}$ & ns & ns & ns \\
\hline Younger and older & Females & ns & $\mathrm{ns}$ & ns & ns & $\mathrm{ns}$ & $\mathrm{ns}$ & $\mathrm{ns}$ & $\mathrm{ns}$ & $\mathrm{ns}$ & ns & ns \\
\hline Younger & Males & NA & NA & NA & NA & NA & NA & NA & NA & NA & NA & NA \\
\hline
\end{tabular}

NA, not available; ns, not significant.

The significance levels of $* * P<0.01$ and $* P<0.05$ were respectively corrected to $P<0.0009(0.01 / 11)$ and $P<0.0045(0.05 / 11)$.

occlusal caries in an early stage of wear, whereas excessive dental wear that surpasses the capacity of secondary dentin production could result in pulp exposure, pulp death, grossgross caries, and, finally, tooth loss.

In bioarchaeological contexts, excessive extramasticatory loads (such as the processing of animal hides and twisting of fibers on teeth and jaws, the use of stone grinding implements, and the incorporation of grit into foods) led to severe tooth wear and pulp exposure (Larsen, 2015). Unfortunately, little is known about the causes of dental wear that may explain the variability across age, sex, and burial type. Current data does not offer evidence of an increase in grinding stone implements during the Pacopampa I and II phases (Megumi Arata, personal communication) and no ethnological example yet reports the twisting of fibers with teeth in the Central Andes.

\section{The wide variation in the prevalence of dental caries and AMTL at Pacopampa}

This study examined the prevalence of caries and AMTL at Pacopampa and compared them across cultural phase, age, sex, and burial type. Results revealed variation according to age (rates increased with age), sex (females exhibited higher carious and AMTL rates than males), and burial type (lower-class individuals had higher carious and AMTL rates than higher-class individuals) (Table 3). These tendencies are consistent with the age, sex, and burial differences detected in dental wear (Table 6).
Population differences in the prevalence of caries and AMTL between Pacopampa and other sites

Turner (1979) showed an increasing trend in carious rates from hunting-gathering to agriculture, using a sample of populations cited globally (hunting-gathering, 1.7\%; agriculture, $8.6 \%$; mixed economy, $4.4 \%$ ). The carious rate of Pacopampa (17.2\%) was higher than the average value of agriculturists, 8.6\% (Turner, 1979) except for individuals from higher-class burials (Supplementary Table 1). Data from zooarchaeological and stable isotope analyses from Pacopampa revealed the increased use of domesticated plants and animals in the Pacopampa II phase (Uzawa, 2008; Takigami and Yoneda, 2017), which is consistent with the carious rates detected at Pacopampa.

Lanfranco and Eggers (2010) examined carious and AMTL rates of the populations of the Early Formative period (4400 \pm 110 BP), Middle Formative period (3920 \pm 110 BP), Late Formative period (Salinar) (2340 $\pm 90 \mathrm{BP})$, and Late Intermediate period (1000-1470 CE) from Peru's northern coast. This chronology, which differs from this study, was directly quoted from Lanfranco and Eggers (2010). The chronological terms were different according to archaeological sites and archaeological cultures. The subsistence of the former was based on fishing, whereas that of the latter three was based on agriculture. The results showed that the carious rates accounted for $21.6 \%, 21.7 \%, 20.7 \%$, and $22.1 \%$ in the Early Formative, Middle Formative, Sali- 
Table 5. Fisher's exact test of rates of carious teeth with one carious lesion and those with more than one carious lesions according to cultural phases, ages, sexes, and burial types

\begin{tabular}{|c|c|c|c|c|c|c|c|c|c|c|c|c|}
\hline \multicolumn{13}{|c|}{ Comparison between cultural phases (Pacopampa I vs. II) } \\
\hline \multirow{2}{*}{ Ages } & \multirow{2}{*}{ Sexes } & \multicolumn{5}{|c|}{ Maxilla } & \multicolumn{5}{|c|}{ Mandible } & \multirow{2}{*}{ Total } \\
\hline & & I & $\mathrm{C}$ & $\mathrm{P}$ & M & Total & I & $\mathrm{C}$ & $\mathrm{P}$ & M & Total & \\
\hline Younger & Females & ns & ns & ns & ns & ns & $\mathrm{ns}$ & ns & ns & $\mathrm{ns}$ & ns & ns \\
\hline \multicolumn{13}{|c|}{ Comparison between ages in the Pacopampa II phase (younger vs. older) } \\
\hline \multirow{2}{*}{ Sexes } & \multirow{2}{*}{ Burial tyapes } & \multicolumn{5}{|c|}{ Maxilla } & \multicolumn{5}{|c|}{ Mandible } & \multirow{2}{*}{ Total } \\
\hline & & I & $\mathrm{C}$ & $\mathrm{P}$ & M & Total & I & $\mathrm{C}$ & $\mathrm{P}$ & $\mathrm{M}$ & Total & \\
\hline Females & Higher-class & ns & ns & ns & ns & ns & ns & ns & ns & ns & ns & ns \\
\hline Females & Lower-class & ns & ns & ns & ns & $\mathrm{ns}$ & $\mathrm{ns}$ & $\mathrm{ns}$ & ns & ns & ns & $\mathrm{ns}$ \\
\hline Males & Lower-class & ns & ns & ns & ns & ns & ns & ns & ns & ns & ns & ns \\
\hline \multicolumn{13}{|c|}{ Comparison between sexes in the Pacopampa II phase (female vs. male) } \\
\hline \multirow{2}{*}{ Ages } & \multirow{2}{*}{ Burial tyapes } & \multicolumn{5}{|c|}{ Maxilla } & \multicolumn{5}{|c|}{ Mandible } & \multirow{2}{*}{ Total } \\
\hline & & I & $\mathrm{C}$ & $\mathrm{P}$ & M & Total & I & $\mathrm{C}$ & $\mathrm{P}$ & M & Total & \\
\hline Younger & Higher-class & NA & NA & NA & NA & NA & NA & NA & NA & NA & NA & NA \\
\hline Younger & Lower-class & ns & $\mathrm{ns}$ & ns & ns & $\mathrm{ns}$ & $\mathrm{ns}$ & $\mathrm{ns}$ & ns & ns & ns & ns \\
\hline Older & Lower-class & $\mathrm{ns}$ & $\mathrm{ns}$ & ns & ns & ns & ns & $\mathrm{ns}$ & ns & ns & ns & ns \\
\hline Younger and older & Lower-class & ns & ns & ns & ns & ns & ns & ns & ns & ns & ns & ns \\
\hline \multicolumn{13}{|c|}{ Comparison between burial types in the Pacopampa II phase (higher-class vs. lower-class) } \\
\hline \multirow{2}{*}{ Ages } & \multirow{2}{*}{ Sexes } & \multicolumn{5}{|c|}{ Maxilla } & \multicolumn{5}{|c|}{ Mandible } & \multirow{2}{*}{ Total } \\
\hline & & I & $\mathrm{C}$ & $\mathrm{P}$ & M & Total & I & $\mathrm{C}$ & $\mathrm{P}$ & M & Total & \\
\hline Younger & Females & ns & ns & ns & ns & ns & ns & $\mathrm{ns}$ & $\mathrm{ns}$ & ns & ns & ns \\
\hline Older & Females & ns & $\mathrm{ns}$ & ns & ns & ns & ns & $\mathrm{ns}$ & ns & ns & ns & ns \\
\hline Younger and older & Females & ns & ns & ns & ns & $\mathrm{ns}$ & ns & ns & ns & ns & ns & ns \\
\hline Younger & Males & NA & NA & NA & NA & NA & NA & NA & NA & NA & NA & NA \\
\hline
\end{tabular}

NA, not available; ns, not significant

The significance levels of $* * P<0.01$ and $* P<0.05$ were respectively corrected to $P<0.0009(0.01 / 11)$ and $P<0.0045(0.05 / 11)$.

nar, and Late Intermediate periods, respectively (Table 7), which were all greater than the average value of agriculturists of Turner (1979). As already mentioned by Lanfranco and Eggers (2010), this is inconsistent with Turner's (1979) expectation of a significant difference in carious rates between fishers and agriculturists. However, the difference in subsistence strategy was not reflected by carious rates, but carious location and AMTL rates (Lanfranco and Eggers, 2010). Occlusal caries was the most frequent occurrence in fishers during the Early Formative period, whereas extraocclusal caries, such as caries of roots and CEJs, increased in agriculturists later on (Lanfranco and Eggers, 2010). The higher prevalence of root caries associated with agricultural development can be linked to periodontal disease, gingival retraction, and dental extrusion, which are caused by the consumption of sucrose and starch, cervical bacterial plaque accumulation, and xerostomia (Lanfranco and Eggers, 2010). Furthermore, the subsistence shift was also accompanied by an increase in AMTL rates (Lanfranco and Eggers, 2010). Thus, it is clear that the development of agriculture in the northern coast was associated with an increase in extraocclusal caries and AMTL. When we compared data from Pacopampa with those of Lanfranco and Eggers (2010), the higher prevalence of caries in roots and CEJs than in occlusal surfaces in the former (Supplementary Table 3) was consistent with the increasing trends in extraocclusal caries in the latter. Secular trends in caries and AMTL across the northern highlands and the northern coast demonstrate some similarities.

We compared the carious and AMTL rates of Pacopampa with Salinar (400-1 BCE) and Gallinazo (1-400 CE) (Gagnon and Wiesen, 2013) (Table 7). This chronology, which differs from that of Lanfranco and Eggers (2010), was directly quoted from Gagnon and Wiesen (2013). The chronological terms were different according to archaeological sites and archaeological cultures. The Pacopampa population exhibited lower frequencies of both dental cries and AMTL than subsequent populations (Table 7). Seki and Yoneda (2005) reconstructed Kuntur Wasi using a carbon and nitrogen isotope and demonstrated that Formative period people consumed fewer $\mathrm{C}_{4}$ foods than people of subsequent eras. If this trend is applied to Formative period societies in the northern highlands, the prevalence of dental caries and AMTL at Pacopampa would be consistent with a lower consumption of $\mathrm{C}_{4}$ foods indicated by isotopic data.

\section{Age and sex differences in the prevalence of caries and AMTL}

It is not surprising that the age-related change in the prevalence of caries and AMTL monotonically increases with age (Table 2). This is because caries and AMTL do not heal after they appear, whereas severe dental wear eliminates 
Table 6. Fisher's exact test of rates of dental wear stages according to cultural phases, ages, sexes, and burial types

\begin{tabular}{|c|c|c|c|c|c|c|c|c|c|c|c|c|}
\hline \multirow{2}{*}{ Ages } & \multirow{2}{*}{ Sexes } & \multicolumn{5}{|c|}{ Maxilla } & \multicolumn{5}{|c|}{ Mandible } & \multirow{2}{*}{ Total } \\
\hline & & I & $\mathrm{C}$ & $\mathrm{P}$ & M & Total & I & $\mathrm{C}$ & $\mathrm{P}$ & M & Total & \\
\hline Younger & Females & ns & ns & ns & ns & ns & ns & ns & ns & ns & ns & ns \\
\hline \multicolumn{13}{|c|}{ Comparison between ages in the Pacopampa II phase (younger vs. older) } \\
\hline \multirow{2}{*}{ Sexes } & \multirow{2}{*}{ Burial tyapes } & \multicolumn{5}{|c|}{ Maxilla } & \multicolumn{5}{|c|}{ Mandible } & \multirow{2}{*}{ Total } \\
\hline & & I & $\mathrm{C}$ & $\mathrm{P}$ & M & Total & I & $\mathrm{C}$ & $\mathrm{P}$ & M & Total & \\
\hline Females & Higher-class & ns & ns & ns & ns & $\mathrm{ns}$ & ns & ns & ns & ns & $* *$ & $* *$ \\
\hline Females & Lower-class & ns & ns & $* *$ & ns & $*$ & ns & $*$ & $* *$ & ns & $* *$ & $* *$ \\
\hline Males & Lower-class & ns & ns & ns & ns & $* *$ & $* *$ & ns & ns & ns & $* *$ & $* *$ \\
\hline \multicolumn{13}{|c|}{ Comparison between sexes in the Pacopampa II phase (female vs. male) } \\
\hline \multirow{2}{*}{ Ages } & \multirow{2}{*}{ Burial tyapes } & \multicolumn{5}{|c|}{ Maxilla } & \multicolumn{5}{|c|}{ Mandible } & \multirow{2}{*}{ Total } \\
\hline & & $\mathrm{I}$ & $\mathrm{C}$ & $\mathrm{P}$ & M & Total & I & $\mathrm{C}$ & $\mathrm{P}$ & M & Total & \\
\hline Younger & Higher-class & ** & ns & ** & ** & $* *$ & $* *$ & ns & $*$ & ** & $* *$ & $* *$ \\
\hline Younger & Lower-class & $* *$ & ns & ns & ns & $* *$ & $* *$ & ns & ns & ns & $* *$ & $* *$ \\
\hline Older & Lower-class & ns & ns & ns & ns & ns & ns & $*$ & ns & ns & $* *$ & ns \\
\hline Younger and older & Lower-class & $*$ & ns & ns & $*$ & $* *$ & $*$ & ns & ns & ns & $* *$ & $* *$ \\
\hline \multicolumn{13}{|c|}{ Comparison between burial types in the Pacopampa II phase (higher-class vs. lower-class) } \\
\hline \multirow{2}{*}{ Ages } & \multirow{2}{*}{ Sexes } & \multicolumn{5}{|c|}{ Maxilla } & \multicolumn{5}{|c|}{ Mandible } & \multirow{2}{*}{ Total } \\
\hline & & $\mathrm{I}$ & $\mathrm{C}$ & $\mathrm{P}$ & M & Total & $\mathrm{I}$ & $\mathrm{C}$ & $\mathrm{P}$ & M & Total & \\
\hline Younger & Females & $*$ & ns & ns & ns & $* *$ & ns & ns & ns & ns & ns & $* *$ \\
\hline Older & Females & ns & ns & ns & ns & ns & ns & ns & ns & ns & ns & ns \\
\hline Younger and older & Females & $* *$ & ns & ns & ns & $* *$ & ns & ns & ns & ns & ns & $* *$ \\
\hline Younger & Males & ns & ns & $* *$ & ns & $* *$ & ns & ns & $*$ & $\mathrm{~ns}$ & $* *$ & $* *$ \\
\hline
\end{tabular}

ns, not significant.

The significance levels of ${ }^{*} P<0.01$ and $* P<0.05$ were respectively corrected to $P<0.0009(0.01 / 11)$ and $P<0.0045(0.05 / 11)$.

occlusal caries (Maat and Van der Velde, 1987).

The higher prevalence of caries and AMTL in females than in males at Pacopampa (Figure 5b; Table 2) is related to cultural and biological factors concerning sex dimorphism in oral health. Higher carious prevalence in females has been reported in modern and ancient human populations (Larsen, 2015) and has been explained by easy access to food during its preparation and early eruption of permanent teeth in females (Lukacs and Largaespada, 2006). Moreover, pregnancy is likely related to sex differences in caries and AMTL: increases in estrogen and progesterone are related to increases in cariogenesis and decreases in mouth $\mathrm{pH}$ (Laine, 2002).

We also observed a higher proportion of root caries in females than in males (Table 4; Supplementary Table 3). Root caries, which is the most frequent carious location at Pacopampa, is generally related to periodontal disease, gingival retraction, and dental extraction due to the consumption of starchy foods in combination with cervical plaque accumulation, and low saliva secretion (Lanfranco and Eggers, 2010).

Together with cultural and biological factors, the use of chicha for rituals of reciprocal exchanges between humans and divine entities (Hastorf and Johannessen, 1993) increased the risk of caries and AMTL in females. The maize was chewed and mixed with saliva in the mouth by females, and then fermented in bottles (Hastorf and Johannessen, 1993). Regarding the production of chicha during the Formative period, Burger and Van der Merwe (1990) advise, based on the results of an isotope ratio analysis of human bones excavated around the Chavín de Huántar site, that it may be traced back to the Late Formative period. Meanwhile, Seki (1998) inferred that chicha production in the Cajamarca basin of Peru's northern highlands could be traced back to the Late Formative period, and archaeological evidence from Pacopampa suggests that the wide-mouthed vessels for chicha boiling and short-necked jars for chicha storage appeared and increased during the Pacopampa II phase (Nagisa Nakagawa, personal communication). Chicha usually worsened oral environments, particularly in females, due to the acidification that resulted in periodontal disease and an increase of cariogenic colonies in the mouth (Lanfranco and Eggers, 2010). The use of chicha at Pacopampa as an explanation of sex differences in caries and AMTL is a fascinating theory that is consistent with the higher prevalence of caries and AMTL in females.

Thus, we concluded that the age and sex differences in the prevalence of caries and AMTL detected in this study could reflect cultural and biological factors.

Burial differences in the prevalence of caries and AMTL

Our results show that the division of burial types at Pacopampa was in accord with the differences in frequencies of caries and AMTL. Individuals from higher-class burials had lower frequencies of caries and AMTL than those from lower-class ones. They also possessed lower frequencies of 

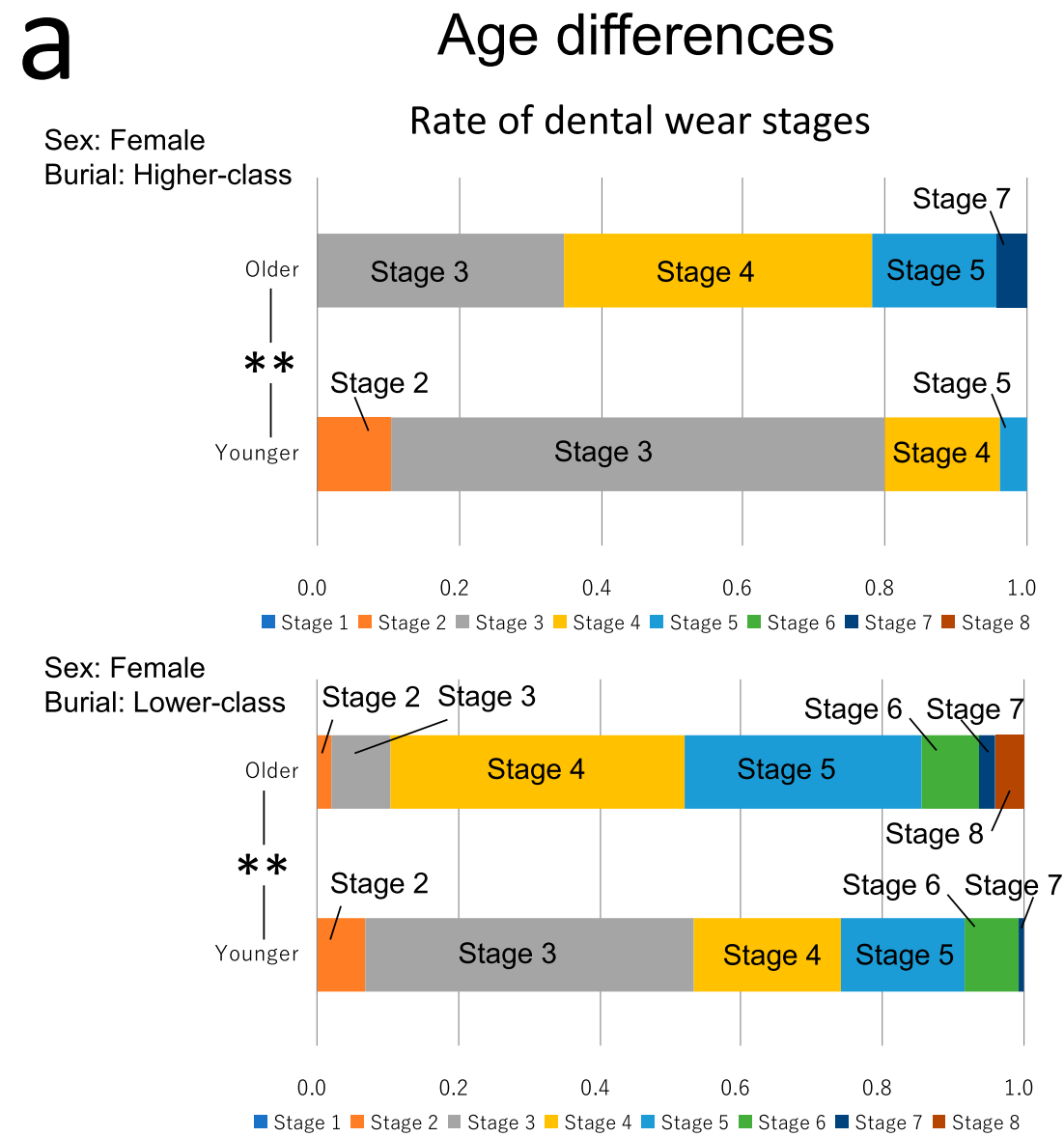

Sex: Male

Burial: Lower-class

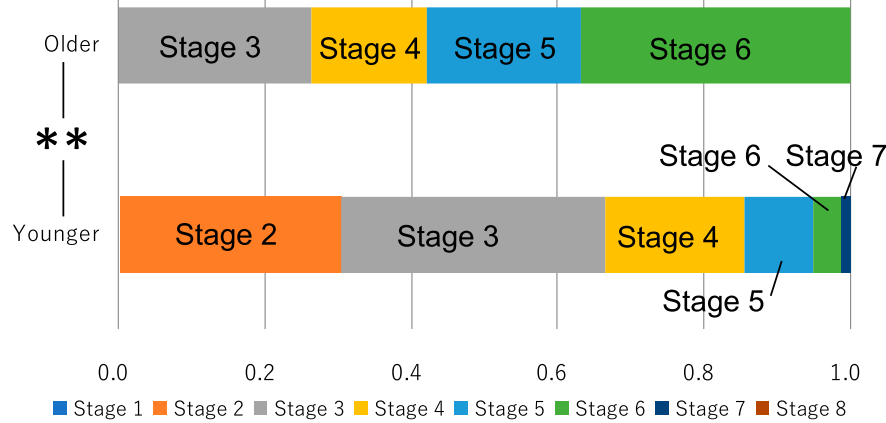

Figure 6. Comparison of rates of dental wear stages according to ages (a), sexes (b), and burial types (c). The significance levels of $* * P<0.01$ and $* P<0.05$ were respectively corrected to $P<0.0009(0.01 / 11)$ and $P<0.0045(0.05 / 11)$.

dental caries and AMTL than other populations from the Early Formative, Middle Formative, Salinar, and the Late Intermediate periods (Lanfranco and Eggers, 2010) and the Salinar and Gallinazo cultures (Gagnon and Wiesen, 2013) (Table 7). The chronological terms were different according to archaeological sites and archaeological cultures.

It is highly likely that observed differences in carious and AMTL rates between burial types reflected social backgrounds consistent with the findings of White (1994), Cucina and Tiesler (2003), and Klaus et al. (2010). Carious rates were higher in low-class individuals than in those who occu- pied higher social positions in the Middle Sicán period (900-1100 CE) in Peru (Klaus et al., 2010) as well as the Classic period (250-900 CE) in Mayan sites like Copan in Honduras (White, 1994), Lamanai in Belize (Whittington, 1999), and Peten at Calakmul (Cucina and Tiesler, 2003), which implies that elite individuals consumed less maize within these societies - along these lines, these studies suggested that lower rates of maize consumption were common for higher-class individuals within these societies.

Based on our findings, we reason that the relationship between burial type and dental pathology at Pacopampa can be 
b

Age: Younger Burial: Higher-class

\section{Sex differences}

\section{Rate of dental wear stages}

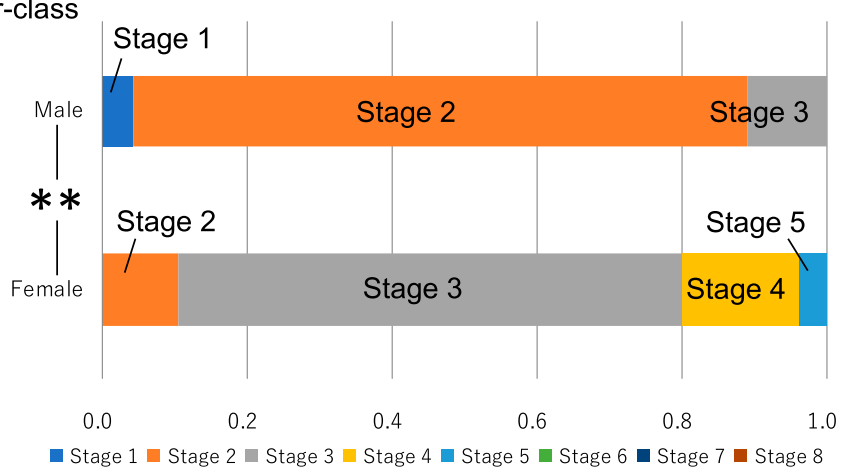

Age: Younger

Burial: Lower-class

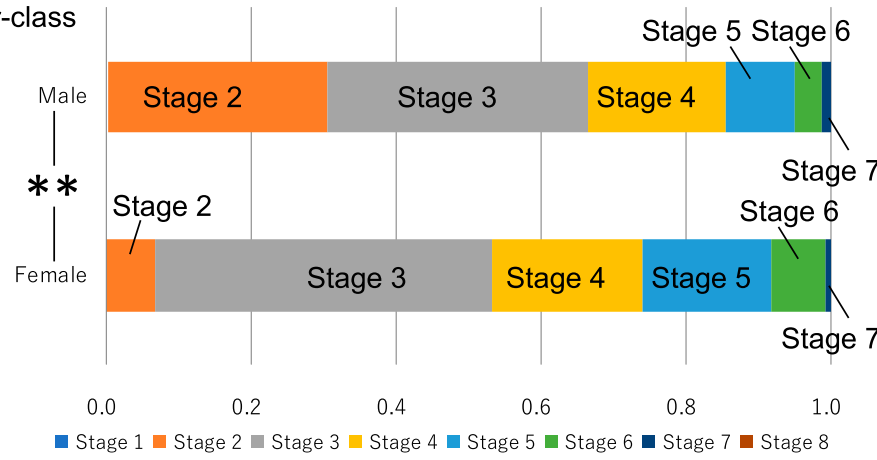

Age: Younger and older Burial: Lower-class

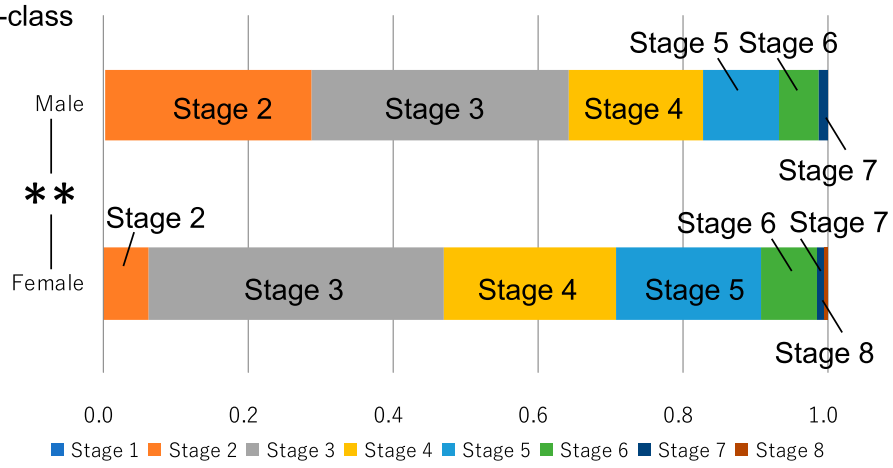

Figure 6. (continued)

attributed to social stratification and subsistence during the Formative period. Stable isotopic data from Kuntur Wasi, a neighboring contemporary site along the western slopes of the Andes mountains demonstrated that individuals from higher-class burials consumed fewer $\mathrm{C}_{4}$ foods than those from lower-class ones (Seki and Yoneda, 2005). Zooarchaeological and stable isotopic data also suggest domesticated animals and plants were prevalent at Pacopampa during the Pacopampa II phase (Uzawa, 2008; Takigami and Yoneda, 2017). Social differences in carious and AMTL rates at Pacopampa could be explained by the idea that individuals from higher-class burials were less exposed to cariogenic foods, under the assumption that the dietary patterns detected at Kuntur Wasi were common in the northern highlands.

At Pacopampa, quantitative differences in maize consumption and dental wear between burial types are similar. Individuals with more severe dental wear would have exhibited higher rates of caries and AMTL because severe dental wear that surpasses the capacity of secondary dentin production can result in pulp exposure, caries, and periodontal diseases. Biological and cultural factors causing wide variations in dental wear accord with social differences across frequencies of caries and AMTL. Although no archaeological evidence yet affirms an increase in grinding implements 


\section{$\mathrm{C}$}

Age: Younger Sex: Female

\section{Burial differences}

\section{Rate of dental wear stages}

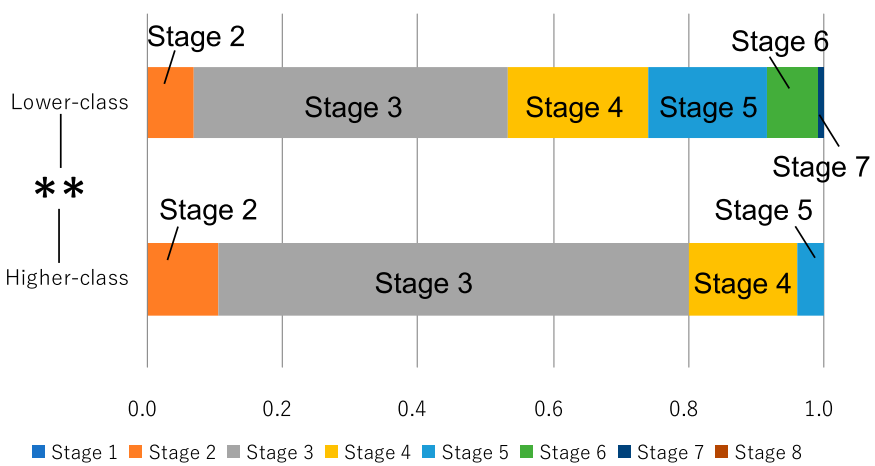

Age: Younger and older

Sex: Female

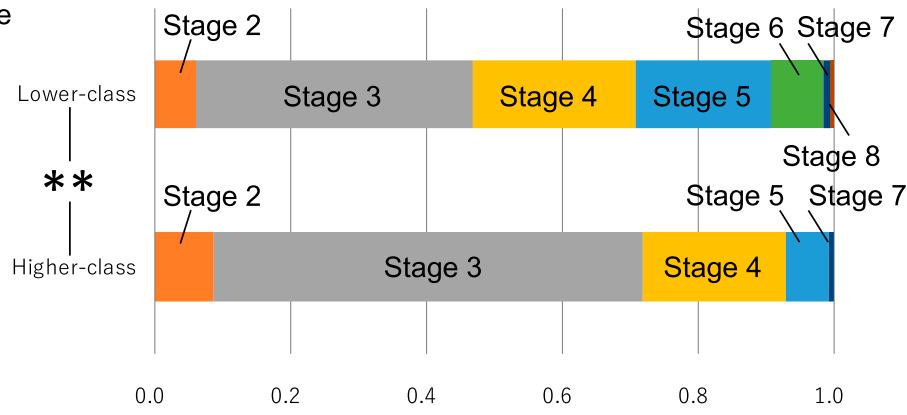

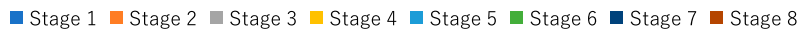

Age: Younger

Sex: Male

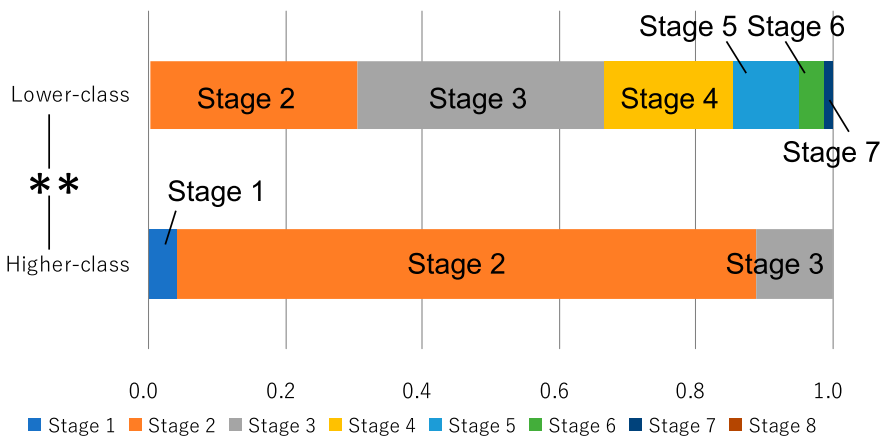

Figure 6. (continued)

during the Pacopampa II phase, we believe that the incorporation of grit into foods cannot be ruled out as a cause of severe dental wear and its inducement of caries and AMTL. This study demonstrated possible social differences in carious rates between higher- and lower-status individuals during the Formative period when social stratification first appeared in ancient Peru; this may be because higher-class individuals may have been free from excessive masticatory labor. We tentatively conclude that social differences in diet and cultural practices may have resulted in a wide variability in carious and AMTL rates in our sample population. Future studies are needed to explore diets using stable isotopic data to test this assumption.

\section{Acknowledgments}

The authors would like to express their gratitude to Megumi Arata and Nagisa Nakagawa for their invaluable help.

\section{Author contributions}

T.N. designed the research, cleaned and reconstructed the human skeletons, collected and analyzed the data, and wrote the paper. Y.S. conducted the fieldwork and revised the paper. K.U. revised the paper. W.M. cleaned and reconstructed the human skeletons and revised the paper. D.M.C. conducted the fieldwork. 
Table 7. Rates of dental caries and AMTL: Pacopampa and comparative data

\begin{tabular}{|c|c|c|c|c|c|}
\hline \multicolumn{6}{|l|}{ Pacopampa } \\
\hline Cultural phases & Ages & Sexes & Burial types & Carious rates & AMTL rates \\
\hline Pacopampa I & Younger & Females & Lower-class & 0.107 & 0.000 \\
\hline Pacopampa II & Younger & Females & Higher-class & 0.037 & 0.009 \\
\hline Pacopampa II & Younger & Females & Lower-class & 0.166 & 0.142 \\
\hline Pacopampa II & Older & Females & Higher-class & 0.269 & 0.000 \\
\hline Pacopampa II & Older & Females & Lower-class & 0.491 & 0.418 \\
\hline Pacopampa II & Younger and older & Females & Higher-class & 0.083 & 0.007 \\
\hline Pacopampa II & Younger and older & Females & Lower-class & 0.216 & 0.201 \\
\hline Pacopampa II & Younger & Males & Higher-class & 0.000 & 0.000 \\
\hline Pacopampa II & Younger & Males & Lower-class & 0.180 & 0.090 \\
\hline Pacopampa II & Older & Males & Lower-class & 0.211 & 0.174 \\
\hline Pacopampa II & Younger and older & Males & Lower-class & 0.182 & 0.095 \\
\hline Total & & & & 0.172 & 0.126 \\
\hline \multicolumn{6}{|l|}{ Lanfranco and Eggers (2010) } \\
\hline Populations & Ages & Sexes & & Carious rates & AMTL rates \\
\hline Early Formative & Adults & Females and males & & 0.216 & 0.126 \\
\hline Middle Formative & Adults & Females and males & & 0.217 & 0.161 \\
\hline Salinar & Adults & Females and males & & 0.207 & 0.269 \\
\hline Late Intermediate period & Adults & Females and males & & 0.221 & 0.115 \\
\hline \multicolumn{6}{|l|}{ Gagnon and Wiesen (2013) } \\
\hline Populations & Ages & Sexes & & Carious rates & AMTL rates \\
\hline Salinar & Adults & Females and males & & 0.194 & 0.218 \\
\hline Gallinazo & Adults & Females and males & & $0.250-0324$ & $0.296-0.377$ \\
\hline
\end{tabular}

AMTL, antemortem tooth loss.

\section{Ethical considerations}

The materials and methods used in this study did not include anything that required approval by the ethical committee of our institute. All necessary permits were obtained for the described study, which complied with all relevant regulations: the permissions of the National Institute of Culture of Peru from 2005 to 2010 (Permission Nos. 1108/INC, 1868/INC, 979/INC, 1061/INC, 815/INC, and 1403/INC) and those of the Peruvian Ministry of Culture from 2011 to 2015 (Permission Nos. 265-2011-DGPC-VMPCIC/MC, 593-2012-DGPC-VMPCIC/MC, 006-2013-DGPA-VMPCIC/ MC, 363-2014-DGPA-VMPCIC/MC, and 270-2015-DGPAVMPCIC/MC).

\section{Funding}

This study was supported by JSPS KAKENHI (grant numbers 23222003, 16H02729, 16H05639, and 20H05138).

\section{Conflict of Interest}

The authors declare that they have no conflict of interest.

\section{References}

Brooks S. and Suchey J.M. (1990) Skeletal age determination based on the os pubis: a comparison of the Acsádi-Nemeskéri and Suchey-Brooks methods. Human Evolution, 5: 227-238.

Bruzek J. (2002) A method for visual determination of sex using the human hip bone. American Journal of Physical Anthropology, 117: 157-168.

Buckberry J.L. and Chamberlain A.T. (2002) Age estimation from the auricular surface of the ilium: a revised method. American Journal of Physical Anthropology, 119: 231-239.

Buikstra J.E. and Ubelaker D.H. (1994) Standards for data collection from human skeletal remains. Proceedings of a seminar at the Field Museum of Natural History. Arkansas Archeological Report Research Series. Arkansas Archeological Survey, Fayetteville.

Burger R.L. (1992) Chavín and the origins of Andean civilization. Thames and Hudson, London.

Burger R.L. and Van Der Merwe N.J. (1990) Maize and the origin of highland Chavín civilization: an isotopic perspective. American Anthropologist, 92: 85-95.

Burger R.L., Lane K.E., and Cooke C.A. (2016) Ecuadorian cinnabar and the prehispanic trade in vermilion pigment: viable hypothesis or red herring? Latin American Antiquity, 27: 22 35.

Costa R.L., Jr. (1980) Age, sex, and antemortem loss of teeth in prehistoric Eskimo samples from Point Hope and Kodiak Island, Alaska. American Journal of Physical Anthropology, 53: 579-587.

Cucina A. and Tiesler N. (2003) Dental caries and antemortem tooth loss in the northern Peten area, Mexico: a biocultural perspective on social status differences among the classic Maya. American Journal of Physical Anthropology, 122: $1-10$.

Frayer D.W. (1984) Tooth size, oral pathology and class distinctions: evidence from the Hungarian Middle Ages. Anthropological Közlemények, 28: 47-54.

Gagnon C.M. and Wiesen C. (2013) Using general estimating equations to analyze oral health in the Moche Valley of Perú. International Journal of Osteoarchaology, 23: 557-572.

Haas J. and Creamer W. (2006) Crucible of Andean civilization. 
Current Anthropology, 47: 745-775.

Hastorf C.A. and Johannessen S. (1993) Pre-Hispanic political change and the role of maize in the Central Andes of Peru. American Anthropologist, 95: 115-138.

Hillson S.W. (1990) Teeth. Cambridge University Press, Cambridge. Hillson S.W. (1996) Dental Anthropology. Cambridge University Press, Cambridge.

Hillson S.W. (2001) Recording dental caries in archaeological human remains. International Journal of Osteoarchaology, 11: 249-289.

Hillson S.W. (2008) The current state of dental decay. In: Irish J.D. and Nelson G.C. (eds.), Technique and Application in Dental Anthropology. Cambridge University Press, Cambridge, pp. 111-136.

Klaus H.D., Centrurion J., and Curo M. (2010) Bioarchaeology of human sacrifice: violence, identity and the evolution of ritual killing at Cerro Cerrillos, Peru. Antiquity, 84: 1102-1122.

Kunos C.A., Simpson S.W., Russell K.F., and Hershkovitz I. (1999) First rib metamorphosis: its possible utility for human age-at-death estimation. American Journal of Physical Anthropology, 110: 303-323.

Laine M.A. (2002) Effect of pregnancy on periodontal and dental health. Acta Odontolofica Scandinavia, 60: 257-264.

Lanfranco L.O. and Eggers S. (2010) The usefulness of caries frequency, depth, and location in determining cariogenicity and past subsistence: a test on early and later agriculturalists from the Peruvian coast. American Journal of Physical Anthropology, 143: 75-91.

Larsen C.S. (2015) Bioarchaeology: Interpreting Behaviour from the Human Skeleton, 2nd edn. Cambridge University Press, Cambridge.

Lovejoy C.O. (1985) Dental wear in the Libben population: its functional pattern and role in the determination of adult skeletal age at death. American Journal of Physical Anthropology, 68: 47-56.

Lovejoy C.O., Meindl R.S., Pryzbeck T.R., and Mensforth R.P. (1985) Chronological metamorphosis of the auricular surface of the illium: a new method for the determination of adult skeletal age at death. American Journal of Physical Anthropology, 68: 15-28.

Lukacs J.R. (1995) The 'caries correction factor': a new method of calibrating dental caries rates to compensate for ante-mortem loss of teeth. International Journal of Osteoarchaeology, 5: 151-156.

Lukacs J.R. and Largaespada L.L. (2006) Explaining sex differences in dental caries prevalence: saliva, hormones, and 'lifehistory' etiologies. American Journal of Human Biology, 18: $540-555$.

Maat G.J.R. and Van der Velde E.A. (1987) The caries-attrition competition. International Journal of Anthropology, 2: 281292.

Matsumoto Y. and Cavero Palomino Y. (2012) Early Horizon gold metallurgy from Campanayuq Rumi in the Peruvian South-central Highlands. Nawpa Pacha: Journal of Andean Archaeology, 32: 115-129.

Molnar S. (1971) Human tooth wear, tooth function and cultural variability. American Journal of Physical Anthropology, 34: $175-189$.

Nagaoka T. and Kawakubo Y. (2015) Using the petrous part of the temporal bone to estimate fetal age at death. Forensic Science International, 248: 188.e1-7.

Nagaoka T., Kawakubo Y., and Hirata K. (2012a) Estimation of fetal age at death from the basilar part of the occipital bone. International Journal of Legal Medicine, 126: 703-711.

Nagaoka T., Seki Y., Morita W., Uzawa K., Paredes D.A., and Morales Chocano D. (2012b) A case study of a high-status human skeleton from Pacopampa in Formative Period Peru. Anatomical Science International, 87: 234-237.

Nagaoka T., Uzawa K., Seki Y., Morales Chocano D. (2017) Pacopampa: early evidence of violence at a ceremonial site in the northern Peruvian highlands. PLoS One, 12: e0185421.

Nagaoka T., Takigami M., Seki Y., Uzawa K., Alemán Paredes D., Andía Roldán P.S., and Morales Chocano D. (2019) Bioarchaeological evidence of decapitation from Pacopampa in the northern Peruvian highlands. PLoS One, 14: e0210458.

Nagaoka T., Seki Y., Villanueva Hidalgo J.P., and Morales Chocano D. (2020) Bioarchaeology of human skeletons from an elite tomb at Pacopampa in Peru's northern highlands. Anthropological Science, 128: 11-17.

Onuki Y. (1998) Kosa shita te no shinden. In: Kato Y. and Seki Y. (eds.), Bunmei no sozoryoku. Kadokawa Shoten. Tokyo, pp. 43-94 (in Japanese).

Onuki Y., Kato Y., and Seki Y. (2010) Kodai Andes shinden kara hajimaru bunmei. Asahi Shinbun Publications, Tokyo. (in Japanese)

Oyamada J., Kitagawa Y., Manabe Y., and Rokutanda A. (2004) Dental pathology in the samurai and commoners of early modern Japan. Anthropological Science, 112: 235-246.

Patterson D.K. (1984) A diachronic study of dental paleopathology and attritional status of prehistoric Ontario Pre-Iroquois and Iroquois populations. Archaeological Survey of Canada, Mercury Series Paper 122, University of Ottawa Press, Ontario.

Phenice T.W. (1969) A newly developed visual method of sexing the os pubis. American Journal of Physical Anthropology, 30: 297-301.

R Core Team (2018) R: A Language and Environment for Statistical Computing. R Foundation for Statistical Computing, Vienna. http://www.R-project.org/

Rose J.C., Armelagos G.J., and Perry L.S. (1993) Dental anthropology of the Nile Valley. In: Davis W.V. and Walker R. (eds.) Biological Anthropology and the Study of Ancient Egypt. British Museum Press, London, pp. 61-74

Sakashita R., Inoue M., Inoue N., Pan Q., and Zhu H. (1997) Dental disease in the Chinese Yin-Shang period with respect to relationships between citizens and slaves. American Journal of Physical Anthropology, 103: 401-408.

Sakura H. (1964) Historical changes in the frequency of dental caries among the Japanese people. Journal of the Anthropological Society of Nippon, 71: 153-177 (in Japanese with English summary).

Scheuer J.L., Musgrave J.H., and Evans S.P. (1980) The estimation of late fetal and perinatal age from limb bone length by linear and logarithmic regression. Annals of Human Biology, 7: 257-265.

Seki Y. (1998) El Período Formativo en el valle de Cajamarca. Boletin de Arqueologia PUCP, 2: 147-160 (in Spanish).

Seki Y. (2014) La diversidad del poder en la sociedad del Período Formativo: una perspectiva desde la sierra norte. In: Seki Y. (ed.), El centro ceremonial andino: nuevas perspectivas para los Períodos Arcaico y Formativo. Senri Ethnological Studies 89, National Museum of Ethnology, Suita, pp. 175-200 (in Spanish).

Seki Y. and Yoneda M. (2005) Cambios de manejo del poder en el Formativo: desde el análisis de la dieta alimenticia. Perpectivas Latinoamericanas, Numero 2, Centro de Estudios Latinoamericanos, Universidad Nanzan, Nagoya, pp. 110-131 (in Spanish).

Seki Y., Villanueva J.P., Sakai M., Alemán D., Ordóñez M., Tosso W., Espinoza A., Inokuchi K., and Morales D. (2008) Nuevas evidencials del sitio arqueológico de Pacopampa, en la sierra norte del Perú. Boletín de Arqueología PUCP, 12: 69-95. (in Spanish)

Shady R.S., Haas J., and Creamer W. (2001) Dating Caral, a preceramic site in the Supe Valley on the central coast of Peru. Science, 292: 723-726.

Takigami M. and Yoneda M. (2017) Shokuryo heno akusesu to kenryoku seisei. In: Seki Y. (ed.), Andes bunmei shinden kara yomitoru kenryoku no sekai. Rinsenshoten, Kyoto, pp. 291317 (in Japanese).

Terada K. and Onuki Y. (1982) The Formative period in the Caja- 
marca Basin, Peru: excavations at Huacaloma and Layzon, 1982. University of Tokyo Press, Tokyo.

Todd T.W. (1920) Age changes in the pubic bone: I. The male white pubis. American Journal of Physical Anthropology, 3: 285334.

Todd T.W. (1921) Age changes in the pubic bone: II. The pubis of the male Negro-White hybrid; III. The pubis of the White female; IV. The pubis of the female Negro-White hybrid. American Journal of Physical Anthropology, 4: 1-70.

Turner C.G., II (1979) Dental anthropological indications of agriculture among the Jomon people of central Japan. X. Peopling of the Pacific. American Journal of Physical Anthropology, 51: 619-635.

Ubelaker D.H. (1989) Human skeletal remains: excavation, analysis, interpretation. Manuals on Archeology Series, No. 2. Taraxacum, Washington.

Uzawa K. (2008) La difusión de los camélidos domesticados en el norte del Perú durante el Periodo Formativo. Boletín de Archeología PUCP, 12: 249-259 (in Spanish).
Wakebe T. (1990) A morphological study of crania of infants and children in the Japanese. Nagasaki Medical Journal, 65: 805824.

Walker P.L. (2008) Sexing skulls using discriminant function analysis of visually assessed traits. American Journal of Physical Anthropology, 136: 39-50.

White C.D. (1994) Dietary dental pathology and cultural change in the Maya. In: Herring A. and Chan L. (eds.), Strength in Diversity: A Reader in Physical Anthropology. Canadian Scholars Press, Toronto, pp. 279-302.

Whittington S.L. (1999) Caries and antemortem tooth loss at Copán: implications for commoner diet. In: White C.D. (ed.), Reconstructing Ancient Maya Diet. University of Utah Press, Salt Lake City, pp. 151-167.

Yamamoto A. (2012) Las rutas interregionales en el periodo Formativo para el norte del Perú y el sur de Ecuador: una perspectiva desde el sitio Ingatambo, valle de Huancabamba. Arqueología y Sociedad, 25: 9-34 (in Spanish). 